\title{
Accelerating shrinkage of Patagonian glaciers from the Little Ice Age ( AD 1870) to 2011
}

\author{
B.J. DAVIES, N.F. GLASSER \\ Institute for Geography and Earth Sciences, Aberystwyth University, Aberystwyth, UK \\ E-mail: bdd@aber.ac.uk
}

\begin{abstract}
We used Little Ice Age (LIA) trimlines and moraines to assess changes in South American glaciers over the last $\sim \mathbf{1 4 0}$ years. We determined the extent and length of $\mathbf{6 4 0}$ glaciers during the LIA ( $\sim \mathrm{AD} 1870$ ) and 626 glaciers (the remainder having entirely disappeared) in 1986, 2001 and 2011. The calculated reduction in glacierized area between the LIA and 2011 is $4131 \mathrm{~km}^{2}(15.4 \%)$, with $660 \mathrm{~km}^{2}$ $(\mathbf{1 4 . 2} \%)$ being lost from the Northern Patagonia Icefield (NPI), $1643 \mathrm{~km}^{2}(11.4 \%)$ from the Southern Patagonia Icefield (SPI) and $306 \mathrm{~km}^{2}(14.4 \%)$ from Cordillera Darwin. Latitude, size and terminal environment (calving or land-terminating) exert the greatest control on rates of shrinkage. Small, northerly, land-terminating glaciers shrank fastest. Annual rates of area loss increased dramatically after 2001 for mountain glaciers north of $52^{\circ} \mathrm{S}$ and the large icefields, with the NPI and SPI now shrinking at $9.4 \mathrm{~km}^{2} \mathrm{a}^{-1}\left(0.23 \% \mathrm{a}^{-1}\right)$ and $20.5 \mathrm{~km}^{2} \mathrm{a}^{-1}\left(0.15 \% \mathrm{a}^{-1}\right)$ respectively. The shrinkage of glaciers between $52^{\circ} \mathrm{S}$ and $54^{\circ} \mathrm{S}$ accelerated after 1986, and rates of shrinkage from 1986 to 2011 remained steady. Icefield outlet glaciers, isolated glaciers and ice caps south of $54^{\circ} S$ shrank faster from 1986 to 2001 than they did from 2001 to 2011.
\end{abstract}

\section{INTRODUCTION}

\subsection{Rationale}

The glaciers of the Patagonian Andes and Tierra del Fuego region are currently shrinking rapidly. Regional assessments of glacier shrinkage are, however, only short-term because they are limited by the temporal availability of satellite observations ( $\sim 40$ years), aerial photography ( $\sim 60$ years) and detailed cartography ( $\sim 60$ years) required to produce accurate reconstructions of former glacier extent. Furthermore, inventories and assessments of modern glacier change in Patagonia have generally been restricted to individual glaciers (e.g. Harrison and Winchester, 2000; Stuefer and others, 2007) or geographically limited to one or two of the large icefields (e.g. Rivera and Cassassa, 2004; Bown and Rivera, 2007; Chen and others, 2007; Schneider and others, 2007; Lopez and others, 2010; Willis and others, 2011). Large parts of the southern Andes still lack detailed inventories (Masiokas and others, 2009a). There are no detailed assessments that encompass the entire region, covering both historically documented shrinkage and remotely sensed observations of change in recent decades. This paper therefore aims, firstly, to establish rates of glacier shrinkage from the Little Ice Age (LIA) to the present day across southern South America, and secondly, to determine how rates of shrinkage changed through the late 20th and early 21 st centuries.

We here present a long (140 years) and spatially wide $(2000 \mathrm{~km}$ in length) record of glacier change in South America $\left(41-56^{\circ} \mathrm{S}\right)$ by calculating changes in glacier length and area between the end of the LIA ( $\sim A D 1870)$ and the years 1986, 2001 and 2011, with some limited additional data from 1975. This is the first study to compare length and area changes since the LIA with change in recent decades for the whole study region. We also analyse spatial and temporal variability in glacier change and the controls thereupon. Our data are available from the Global Land Ice Measurements from Space (GLIMS) database (www.glims.org).

\subsection{Study area}

The Andes is the longest continental mountain range in the world, stretching $7000 \mathrm{~km}$ along the coast of South America and reaching almost $7000 \mathrm{ma.s.l}$. In our study area, the mountains reach a maximum of $4000 \mathrm{~m}$ a.s.l., decreasing to $1500-2000 \mathrm{~m}$ in southernmost South America. Between $38^{\circ} \mathrm{S}$ and $56^{\circ} \mathrm{S}$ there are four major ice masses (the Northern and Southern Patagonia Icefields, Gran Campo Nevado (GCN) and Cordillera Darwin) and numerous snow- and icecapped volcanoes and icefields (Fig. 1). Our study area focuses on the Patagonian Andes and Tierra del Fuego, from $41^{\circ} \mathrm{S}$ to $56^{\circ} \mathrm{S}$. This region has been the subject of numerous detailed local studies covering glacier behaviour over various timescales, and there is good historical and geomorphological evidence for glacier fluctuations since the LIA (summarized by Masiokas and others, 2009a).

The Chilean Lake District $\left(38-42^{\circ} \mathrm{S}\right)$ is characterized by shrinking glaciers on active volcanic cones, with frequent ash deposition insulating the ice. These volcano ice caps have been thinning since observations began in 1961, with more rapid thinning from 1981 to 1998. Their negative mass balances were caused by decreased precipitation and upper-tropospheric warming over the last 30 years (Bown and Rivera, 2007). Equilibrium-line altitudes (ELAs) are at $\sim 1600 \mathrm{~m}$ at $43^{\circ} \mathrm{S}$ (Rivera and others, 2012). Glaciers north of $42^{\circ} \mathrm{S}$ receive higher precipitation during winter months than glaciers between $42^{\circ} \mathrm{S}$ and $49^{\circ} \mathrm{S}$ (Sagredo and Lowell, 2012).

The Northern Patagonia Icefield (NPI) covers an area of $\sim 4200 \mathrm{~km}^{2}$ at $47^{\circ} \mathrm{S}$ (Fig. 2a). Its survival at such a low latitude is attributed to a large volume of precipitation (up to $10000 \mathrm{~mm}$ w.e. $\mathrm{a}^{-1}$ ) and to the cool temperatures associated with the high elevation of the Andes (Rott and others, 1998; Michel and Rignot, 1999; see temperature transects in Fig. 1). The NPI is characterized by high ablation rates, steep mass-balance and precipitation gradients and high ice velocities (Lopez and others, 2010). The glaciers of the 


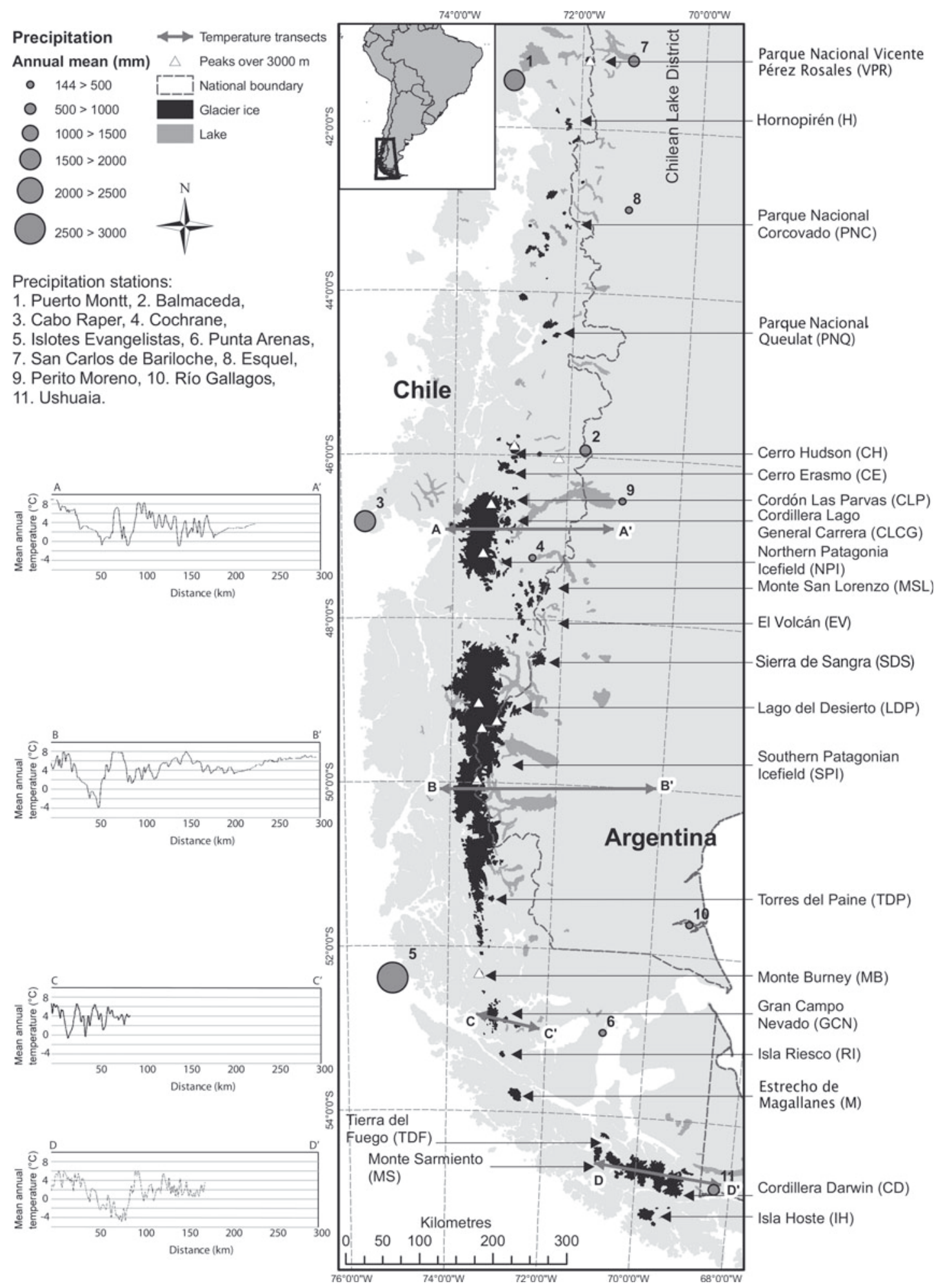

Fig. 1. Location of the main icefields and glaciers in southern South America, showing abbreviations used in text and tables. The inset shows the wider location of the study area. Mean annual temperature data for the four temperature transects were obtained from Hijmans and others (2005) from a $1 \mathrm{~km}$ resolution raster dataset. Note decreasing temperatures over the icefields and in areas of high elevation. Local variations reflect the influence of fjords, rivers and mountains. Precipitation data for stations where there were records longer than 10 years were obtained from the Dirección Meteorológica de Chile. Note the strong west-east precipitation gradients that exist across the study area and the low number of stations; precipitation values at each glacier are therefore uncertain. Lakes larger than $15 \mathrm{~km}^{2}$ are shown.

$\mathrm{NPI}$ extend below the $0^{\circ} \mathrm{C}$ isotherm, and the snowline is generally below $2000 \mathrm{~m}$ a.s.I. (Sagredo and Lowell, 2012). The recent fluctuations of NPI outlet glaciers have been extensively studied (Aniya, 1988, 1995, 1996, 1999, 2001, 2007; Harrison and Winchester, 2000; Araneda and others, 2007; Chen and others, 2007; Lopez and others, 2010).
Glaciar San Rafael is the only tidewater glacier of the NPI; it is the world's lowest-latitude tidewater glacier and is among the fastest-flowing glaciers in the world (Warren and others, 1995; Koppes and others, 2011). Peak velocities of $19.7 \pm 1.2 \mathrm{~m} \mathrm{~d}^{-1}$ were observed in 2007 by Willis and others (2011). Laguna San Rafael is dammed by large arcuate 

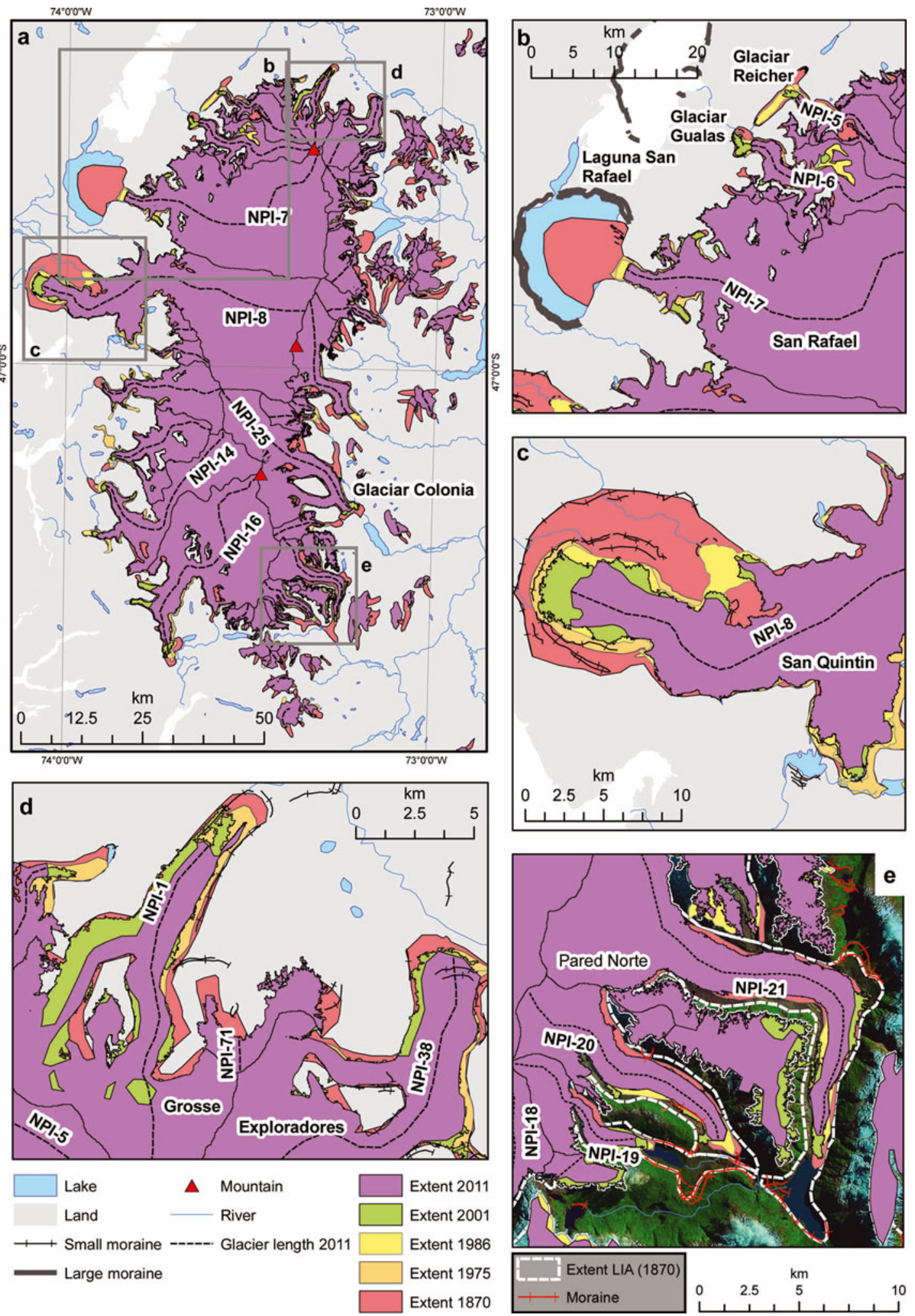

Fig. 2. Examples of glacier change for parts of the NPI. Note the trimlines and mapped moraines, which were used to reconstruct maximum glacier extent during the LIA (AD 1870). Dashed black lines illustrate mapped glacier lengths for 2011; previous years follow the same flowline. (a) Overview of the NPI. (b) The snout of Glaciar San Rafael. (c) The snout of Glaciar San Quintin. In this case, because of welldocumented evidence, the outermost moraines were used in the definition of the LIA. (d) The northern NPI, including NPI-1 (Glaciar Grosse). (e) Landsat ETM+ image from 2001, with clearly defined trimlines and moraines demarking the LIA extent (dashed white outline).

moraines that were formed during a mid-Holocene readvance of the glacier (Fig. 2b; Harrison and others, 2012).

The Southern Patagonia Icefield (SPI) stretches along the southern Andes, reaching altitudes of $3400 \mathrm{~m}$. It is drained by temperate outlet glaciers, terminating on land or in proglacial lakes or tidal fjords (Aniya and others, 1997). Variations in glacier frontal positions have been studied since the 1940s, with long-term retreat (Aniya and others, 1992, 1996, 1997; Aniya, 1996, 1999; Lopez and others, 2010) and thinning (Aniya, 1995; Naruse and others, 1997; 
Naruse and Skvarca, 2000) being evident in the majority of the glaciers. Glaciers are generally larger than in the NPI, and Glaciar Pio XI is the largest in South America $\left(1265 \mathrm{~km}^{2}\right)$ (Aniya and others, 1996).

The NPI and SPI have been shrinking dramatically ever since their LIA maxima, which are securely dated to AD 1870 (Glasser and others, 2011), and are now shrinking at an increasing rate in response to regional climate change. Rignot and others (2003) estimated that the two icefields jointly contributed $0.042 \pm 0.002 \mathrm{~mm} \mathrm{a}^{-1}$ to global mean sea-level rise in the period $1968 / 1975$ to 2000 but that this doubled to $0.105 \pm 0.011 \mathrm{~mm} \mathrm{a}^{-1}$ from 1995 to 2000. Chen and others (2007) estimated the ice loss rate for the Patagonia icefields from 2002 to 2006 to be $27.9 \pm 11 \mathrm{~km}^{3} \mathrm{a}^{-1}$, equivalent to an average loss of $\sim 1.6 \mathrm{~m} \mathrm{a}^{-1}$ ice thickness change if evenly distributed over the entire glacier area and a global contribution to sea-level rise of $+0.078 \pm 0.031 \mathrm{~mm} \mathrm{a}^{-1}$. Ivins and others (2011) estimated ice loss rates for the NPI and SPI of $26 \pm 6 \mathrm{Gta}^{-1}$ from 2003 to 2009, using a combination of data from the Gravity Recovery and Climate Experiment (GRACE) satellite and GPS bedrock uplift data. The background to these changes is presumed to be the global surface temperature increase of $+0.6 \pm 0.2^{\circ} \mathrm{C}$ in the 20th century (Vaughan and others, 2001), resulting in widespread glacier wastage and shrinkage (Aniya, 1988; Ramirez and others, 2001; Arendt and others, 2002; Meier and others, 2003; Cook and others, 2005; WGMS, 2008).

Gran Campo Nevado $\left(53^{\circ} \mathrm{S}\right)$ is an ice cap with several steep outlet glaciers $\left(199 \mathrm{~km}^{2}\right.$; Schneider and others, 2007; Fig. 1), which may mean that it responds faster to climatic changes than the NPI or SPI (Möller and others, 2007). It is at much lower altitudes than the NPI or SPI, with mountain summits from 1000 to $1700 \mathrm{~m}$ high, and with outlet glaciers reaching sea level. Mean annual temperatures here are $+5.7^{\circ} \mathrm{C}$, but the ice cap survives because of extremely high precipitation (Möller and Schneider, 2008).

Isla Riesco $\left(52^{\circ} \mathrm{S}\right)$ is $\sim 130 \mathrm{~km}$ long and $50 \mathrm{~km}$ wide, with moderate precipitation on its eastern part $\left(<1000 \mathrm{~mm} \mathrm{a}^{-1}\right)$, which is leeward of the Andes. The western part of the island is within the main belt of the Andes, with high precipitation rates (Fig. 1). The mountains reach 1830 ma.s.l., with several small ice caps and mountain glaciers (Casassa and others, 2002). All these glaciers terminate on land, with the exception of a few small freshwater lakes.

Tierra del Fuego is an archipelago off southernmost South America (Fig. 1), with many small ice caps and mountain glaciers, as well as the Cordillera Darwin icefield. Cordillera Darwin is the most southerly icefield in the study region, at $54^{\circ} 30^{\prime} \mathrm{S}$, with topography constraining the ice masses (in comparison to the NPI and SPI, where ice-sheds separate the catchments (Warren and Aniya, 1999)). The mountains reach 2469 ma.s.l., and many of the glaciers calve into the ocean. The area receives more precipitation than does land to the east and north, and glaciers south of the ice divide receive far more precipitation than those north of the ice divide, as a result of the orographic rain shadow (Holmlund and Fuenzalida, 1995). The glaciers of Tierra del Fuego and Cordillera Darwin receive uniform precipitation throughout the year, and have an annual temperature range of $\sim 7.4^{\circ} \mathrm{C}$ and a mean annual temperature of $1.2^{\circ} \mathrm{C}$ (Sagredo and Lowell, 2012). The mass balance of Glaciar Martial Este, Tierra del Fuego, was negative $\left(-772 \mathrm{~mm}\right.$ w.e. $\left.\mathrm{a}^{-1}\right)$ from 1960 to 2006 (Buttstädt and others, 2009).

\subsection{Regional climate}

\subsubsection{Precipitation}

The climate of Patagonia is dominated by Southern Hemisphere westerlies and equatorial Pacific sea surface temperatures, which regulate the El Niño Southern Oscillation (ENSO) and the Pacific Decadal Oscillation (Aravena and Luckman, 2009; Garreaud and others, 2009). The Andean mountain chain is a significant orographic barrier to the predominant westerlies, which results in steep precipitation gradients across the mountain chain (Masiokas and others, 2008; cf. Fig. 1). Precipitation between $40^{\circ} \mathrm{S}$ and $43^{\circ} \mathrm{S}$ declined between 1950 and 2000 (Aravena and Luckman, 2009). Furthermore, ENSO events, which are associated with reduced precipitation, have become more frequent since 1976 (Giese and others, 2002; Montecinos and Aceituno, 2003; Bown and Rivera, 2007).

\subsubsection{Temperature}

Throughout the Andes, there has been a trend to increasing elevation of the $0^{\circ} \mathrm{C}$ isotherm, with an ELA rise attributed to this warming. The warming is regionally variable, with slight cooling or non-significant warming in southern Chile after 1976 (Carrasco and others, 2008). Tree ring data from the southern Andes dating back to AD 1640 show that 20thcentury temperatures have been anomalously warm; the mean annual temperatures for 1900-90 for the northern and southern sectors of the Andes are $0.53^{\circ} \mathrm{C}$ and $0.86^{\circ} \mathrm{C}$ higher than the 1640-1899 means (Villalba, 1994).

In the Chilean Lake District $\left(38-42^{\circ} \mathrm{S}\right)$, the upper troposphere has been warming at +0.019 to $+0.031^{\circ} \mathrm{Ca}^{-1}$. However, low-altitude cooling has been detected at several meteorological stations, particularly Puerto Montt and stations further north (Bown and Rivera, 2007). After 1976, changes in the Pacific Decadal Oscillation were observed, with a period of increased temperatures across the southern Andes (Villalba and others, 2003). Sagredo and Lowell (2012) hypothesize that under a changing climatic regime, glaciers in the NPI, SPI and Cordillera Darwin will become increasingly sensitive southwards to mean temperature rises and more uniform precipitation throughout the year.

\section{METHODS}

\subsection{Data}

Orthorectified (level 1G) Landsat Thematic Mapper (TM) images from 1985-87 and Landsat Enhanced TM Plus (ETM+) images from 2001-02 and 2010-11 were acquired pre-registered to Universal Transverse Mercator (UTM) World Geodetic System 1984 ellipsoidal elevation (WGS84), zone $18 \mathrm{~S}$ projection (Appendix A). These images have a large swath $(185 \mathrm{~km})$ and reasonable spatial resolution $(30 \mathrm{~m})$, and a geopositional accuracy of better than $\pm 50 \mathrm{~m}$ (Tucker and others, 2004). The 2010-11 images have striping artefacts, caused by failure of the scan-line corrector (SLC) on the Landsat sensor in 2003.

For the NPI, additional data were obtained for 1975 from Aniya (1988). These data originate from 1974/75 vertical aerial photographs, which were used to create a map by the Instituto Geográfico Militar, Chile, which was subsequently used in a glacier inventory by Aniya (1988).

Elevation data were derived from the Shuttle Radar Topography Mission (SRTM) digital elevation model (DEM) version 4.1 (hereafter SRTM4), at 3" resolution (90 m) (Jarvis 
Table 1. Identification of glaciological and geomorphological features. After Glasser and others (2005, 2008)

\begin{tabular}{|c|c|c|c|c|}
\hline \multirow{2}{*}{$\begin{array}{l}\text { Landform/ } \\
\text { feature }\end{array}$} & \multicolumn{2}{|c|}{ Identification criteria } & \multirow[t]{2}{*}{ Possible errors } & \multirow[t]{2}{*}{ Glaciological significance } \\
\hline & Morphology & Colour/structure/texture & & \\
\hline $\begin{array}{l}\text { Debris-covered } \\
\text { snout }\end{array}$ & $\begin{array}{l}\text { There may be arcuate or linear } \\
\text { glaciological structures, ponds or } \\
\text { bare ice visible. Where the glacier } \\
\text { terminates in a lake, a fragmented } \\
\text { floating margin may be visible. }\end{array}$ & $\begin{array}{l}\text { Dark brown. Sharp transition } \\
\text { to vegetation. Surface is rough } \\
\text { and pitted. }\end{array}$ & $\begin{array}{l}\text { Supraglacial debris cover on } \\
\text { snout may be confused with } \\
\text { lateral or terminal moraines; } \\
\text { similar spectral properties to } \\
\text { rock valley sides. }\end{array}$ & $\begin{array}{l}\text { Denotes glacier extent. } \\
\text { May indicate } \\
\text { downwasting. }\end{array}$ \\
\hline Trimlines & $\begin{array}{l}\text { Sub-horizontal lines on valley sides } \\
\text { separating areas of vegetated and } \\
\text { non-vegetated land or areas with } \\
\text { different types of vegetation. }\end{array}$ & $\begin{array}{l}\text { Sharp altitudinal change in } \\
\text { surface colour and texture as } \\
\text { a result of changes in } \\
\text { vegetation cover. }\end{array}$ & $\begin{array}{l}\text { Possible but unlikely; confusion } \\
\text { with sub-horizontal features as } \\
\text { lake shorelines. }\end{array}$ & $\begin{array}{c}\text { Former vertical extent } \\
\text { of glaciers. }\end{array}$ \\
\hline $\begin{array}{l}\text { Terminal } \\
\text { moraines }\end{array}$ & $\begin{array}{l}\text { Prominent cross-valley single or } \\
\text { multiple ridges with positive relief. } \\
\text { Linear, curved, sinuous or } \\
\text { saw-toothed plan. }\end{array}$ & $\begin{array}{l}\text { Shadowing due to change in } \\
\text { relief and change in colour } \\
\text { when moraines are vegetated. }\end{array}$ & $\begin{array}{l}\text { Possible, but unlikely, } \\
\text { confusion with trimlines } \\
\text { where moraines have a low } \\
\text { relative height. }\end{array}$ & $\begin{array}{l}\text { Mark the former terminal } \\
\text { position of outlet } \\
\text { glaciers. Innermost } \\
\text { moraine is taken as the } \\
\text { LIA limit except where this } \\
\text { has been published } \\
\text { elsewhere. }\end{array}$ \\
\hline Cirques & $\begin{array}{l}\text { Large amphitheatre-shaped hollows } \\
\text { on mountain flanks or incised into } \\
\text { plateau edges. Sharp boundaries } \\
\text { with surrounding terrain. }\end{array}$ & $\begin{array}{l}\text { Shadowing due to change in } \\
\text { height or relative relief. Cirque } \\
\text { floors may be different in colour } \\
\text { from surrounding land. }\end{array}$ & $\begin{array}{l}\text { Possible, but unlikely, confusion } \\
\text { with mass-movement or landslip } \\
\text { scars, particularly beneath } \\
\text { volcanic plateau. }\end{array}$ & $\begin{array}{l}\text { Indicates presence of } \\
\text { localized or restricted } \\
\text { mountain glaciation. }\end{array}$ \\
\hline
\end{tabular}

and others, 2008), providing elevation data from February 2000 (Appendix B). Vertical and horizontal errors are $\sim 10 \mathrm{~m}$ (Farr and others, 2007). SRTM4 is a void-filled DEM, which may introduce inaccuracies in areas of steep topography (Reuter and others, 2007; Frey and Paul, 2012), but is suitable for use in glacier inventories (Frey and Paul, 2012). There is uncertainty in glacier elevation in our 2001 census as a result of differing times of image capture between the SRTM4 and Landsat data.

\subsection{Glacier digitization for 1986, 2001 and 2011}

Our methods follow GLIMS protocols, with each glacier between $41^{\circ} \mathrm{S}$ and $56^{\circ} \mathrm{S}$ (Fig. 1; Table 1) being manually digitized as a separate polygon (Rau and others, 2005; Raup and others, 2007a,b; Paul and others, 2009; Racoviteanu and others, 2009; Svoboda and Paul, 2009; Raup and Khalsa, 2010). We digitized glacier outlines in a GIS (ESRI ArcMap 9.3) at 1:10000 scale using cloud- and snow-free Landsat satellite images available from summer months in 1985/86, 2000/01 and 2010/11 (Appendix A). Using data from Aniya (1988), the extents of 38 outlet glaciers for the NPI were also digitized for 1975. Ice divides on the icefields were determined from previous publications (Aniya, 1996, 1999; Aniya and others, 1996; Rignot and others, 2003; Bown and Rivera, 2007; Rivera and others, 2007; Lopez and others, 2010), and downloaded from GLIMS where possible (e.g. Schneider and others, 2007) to ensure consistency with other studies, or by using high points, nunataks, glaciological structures or breaks in slope (Glasser and Scambos, 2008; Davies and others, 2012; Table 1). All icefield outlet glaciers and ice caps and all mountain glaciers that could be clearly discriminated in the satellite images (as distinct from snow) and that were larger than $0.1 \mathrm{~km}^{2}$ (because of image resolution and the danger of misclassification of snowpatches) were digitized in this study. Near the NPI, SPI, Cordillera Darwin and GCN, there are numerous small isolated glaciers with a 'Mountain glacier' classification, which have been considered separately (Northern Patagonian mountain glaciers (NPMG), Southern Patagonian mountain glaciers (SPMG), Cordillera Darwin mountain glaciers (CDMG) and Gran Campo Nevado mountain glaciers (GCMG)).

\subsection{Geomorphological mapping to determine LIA extent}

Glacier extent at the LIA was digitized for glaciers between $38^{\circ} \mathrm{S}$ and $56^{\circ} \mathrm{S}$ (Fig. 1) (Glasser and others, 2011) for glaciers with clear trimlines and moraines. The LIA extent was inferred from geomorphological evidence, including trimlines and terminal moraines in front of contemporary glaciers (e.g. Fig. 2), which were identified according to previously defined criteria (Table 1). The inferred LIA glacier extents were checked against known LIA positions from published valley-scale dendrochronological and lichenometric dating studies, for example for the Chilean Lake District (Bown and Rivera, 2007), NPI (Villalba, 1994; 
Harrison and Winchester, 2000; Winchester and Harrison, 2000; Glasser and others, 2002, 2004; Araneda and others, 2007; Harrison and others, 2007, 2012), SPI (Aniya, 1995, 1996; Masiokas and others, 2009a,b; Rivera and others, 2011), GCN (Koch and Kilian, 2005) and Cordillera Darwin (Kuylenstierna and others, 1996; Masiokas and others, 2009a). In situations where multiple trimlines or moraines exist, we drew the LIA limit at the trimline or moraine closest to the contemporary glacier snout (see Fig. 2 for examples from the NPI). At those glaciers where there is no visible evidence of shrinkage since the LIA or where the LIA limits are ambiguous or difficult to establish (e.g. for some fjordterminating glaciers of the SPI), the limits are assumed to be the same as in 1975 or 1986 (the earliest possible data available). Our results are therefore minimum estimates of ice shrinkage over the time period $\sim A D$ 1870-2011.

\subsection{Glacier attribute data}

Attribute data for each glacier polygon include a unique Local ID (the same as that used in previous inventories, where appropriate), GLIMS ID (Raup and Khalsa, 2010), any established glacier name, $X$ and $Y$ coordinates of the centroid, surface area $\left(\mathrm{km}^{2}\right)$, primary classification (Rau and others, 2005), form, frontal characteristics, ID and acquisition date of the satellite image, analyst name and analysis time. For LIA polygons, any published evidence of LIA ice extent and associated references are also included. Glacier aspect (azimuth of the accumulation area; Evans, 2006) was estimated using vectors that follow the steepest part of the glacier accumulation area. Glacier length was measured for 520 glaciers according to standard procedures (Lopez and others, 2010; Davies and others, 2012), following the longest flow pathway from the highest point on the ice divide to the glacier tongue (see Fig. 2). Minimum, maximum and median elevations and slopes for 2000 were derived automatically for each glacier in the GIS following analysis of SRTM4 (Paul and others, 2009; Frey and Paul, 2012).

\subsection{Uncertainty}

Digitized glacier lengths and outlines are accurate to $\pm 30 \mathrm{~m}$ (i.e. \pm 1 pixel). Accuracy may be less in the centre of icefields, where ground control points are scarce, but as the same ice divides are used for each year inventoried, the uncertainty that this introduces into relative change measurement is limited. There may be inaccuracies where snow cover on nunataks in the centre of the icefields or adjacent to the ice edges has been misclassified as ice. We used qualitative methods to identify errors in glaciers with seasonal snow or large deviations in area between each year mapped, and manually improved these with additional Landsat images. Indeed, seasonal snow cover is not a significant problem in Patagonia because of the strong seasonality, and there is very little lying snow in the summer months near the glacier snouts. Where snow and ice is difficult to discriminate (e.g. on snow-capped mountains and volcanoes), glaciers have not been digitized.

Other potential sources of uncertainty include ice-divide and drainage basin identification, error in co-registration (Granshaw and Fountain, 2006), clouds and shadows, and delineation of debris-coved glaciers (Bolch and others, 2010). However, this uncertainty was limited with manual digitization at resolutions up to $1: 10000$ (Table 1), which is more accurate than automatic classification (cf. Jiskoot and others, 2009), particularly when dealing with debris-covered glaciers (Paul, 2002). Automatic classification is particularly useful and suitable when analysing larger datasets comprising >1000 glaciers with clean ice. However, we acknowledge that delineating the boundary of debris-covered ice is very difficult with images of this resolution. A further source of error is the striping on Landsat ETM+ images taken after 2003, and it was necessary to interpolate across the stripes. This was mitigated by using numerous overlapping images, so that interpolating across large stripes near the margins of the image was not required.

Statistical quantification of errors is difficult without ground control points, high-resolution satellite images or ground-truthing in the week that the satellite image was taken (Svoboda and Paul, 2009). In order to quantify uncertainty, we conducted error analysis of the digitization of six NPI outlet glaciers in 1986 (i.e. the same glacier was independently digitized five times), both with and without debris cover and with grounded and floating termini (cf. Stokes and others, 2007). This yielded an average standard deviation of $+0.3 \mathrm{~km}^{2}$, or $2.0 \%$ of the area. Analysis of the area changes of glaciers is therefore considered to be accurate to within $2.0 \%$. The glaciological uncertainty of ice divides is likely to be far larger than the mapping uncertainty, which has little influence on the final glacial outline, especially when comparing ice margin change from different years.

\subsection{Analysis of glacier change}

There are four kinds of data resulting from this study: glacier descriptors (area, length, primary classification, aspect, frontal characteristics, etc.), length changes $\left(\mathrm{km} \mathrm{a}^{-1} ; \mathrm{ma}^{-1}\right)$, area changes $\left(\mathrm{km}^{2} ; \%\right)$ and annual rates of change $\left(\% \mathrm{a}^{-1}\right)$ (cf. Bolch and others, 2010). We use 'recession' where length changes are discussed and 'shrinkage' for area changes. Annual rates of change were calculated by dividing the area change by the time between analyses for each glacier (time is taken from the date the satellite image was acquired). These are the only results that can be directly compared over different time periods and different glaciers, because of the different lengths of time between analyses (i.e. $\sim 116$ years from 1870 to $1986, \sim 15$ years from 1986 to 2001 , and $\sim 10$ years from 2001 to 2011, depending on when the satellite image for each glacier was acquired).

\section{RESULTS}

\subsection{Characteristics of South American glaciers in 2011}

In 2011, 626 glaciers were considered in our assessment, which included 386 major outlet glaciers from the main icefields (44 from the NPI, 161 from the SPI, 35 from GCN and 99 from Cordillera Darwin) (Table 2). These four principal icefields dominate the glacierized area (Fig. 3a). Glacier sizes in 2011 ranged from 0.1 to 1344 km² (SPI-137; Pio XI) (Table 2). Although there are many small glaciers, a few large glaciers made up the majority of the glacierized area (Fig. 3a). The mountain ranges beneath the SPI, NPI, GCN and El Volcán are orientated north-south, resulting in a predominantly west-east aspect for the outlet glaciers (Fig. 3b).

In the study region there were 233 outlet, 95 valley and 229 mountain glaciers, 26 ice caps and 38 icefields, with outlet glaciers dominating the glacierized area. Although mountain glaciers are numerous, they made up only a small 
Table 2. Summary of the glacier inventory, divided into regions. Regions are ordered north to south. Location in decimal degrees

\begin{tabular}{|c|c|c|c|c|c|c|c|c|c|c|c|c|c|}
\hline \multirow[t]{3}{*}{ Region } & \multirow[t]{3}{*}{$\begin{array}{l}\text { Region } \\
\text { code }\end{array}$} & \multirow[t]{3}{*}{ Lat. } & \multirow[t]{3}{*}{ Long. } & \multirow{3}{*}{$\begin{array}{c}\text { Largest } \\
\text { glacier } \\
\text { in } 2011 \\
\text { km }^{2}\end{array}$} & \multirow{3}{*}{$\begin{array}{c}\text { Smallest } \\
\text { glacier } \\
\text { in } 2011 \\
\\
\mathrm{~km}^{2}\end{array}$} & \multirow{2}{*}{\multicolumn{2}{|c|}{$\begin{array}{c}\text { Mean } \\
\text { topographic } \\
\text { data in } 2000 \\
\text { Elevation Slope }\end{array}$}} & \multicolumn{2}{|c|}{$\begin{array}{l}\text { Number of } \\
\text { glaciers }\end{array}$} & \multicolumn{4}{|c|}{ Glacierized area } \\
\hline & & & & & & & & 1870 & $\begin{array}{c}1986- \\
2011\end{array}$ & 1870 & 1986 & 2001 & 2011 \\
\hline & & & & & & ma.s.I. & $\circ$ & & & $\mathrm{km}^{2}$ & $\mathrm{~km}^{2}$ & $\mathrm{~km}^{2}$ & $\mathrm{~km}^{2}$ \\
\hline $\begin{array}{l}\text { Parque Nacional } \\
\text { Vicente Pérez } \\
\text { Rosales }\end{array}$ & VPR & -41.15 & -71.88 & 65.8 & 65.8 & 2158 & 23 & 1 & 1 & 89.4 & 72.1 & 71.2 & 65.8 \\
\hline Hornopirén & $\mathrm{H}$ & -41.99 & -72.19 & 32 & 1.4 & 1614 & 20 & 8 & 8 & 146.4 & 113.1 & 104.3 & 96.1 \\
\hline $\begin{array}{l}\text { Parque Nacionale } \\
\text { Corcovado }\end{array}$ & PNC & -43.49 & -72.5 & 82 & 0.4 & 1492 & 23 & 16 & 16 & 453.4 & 330.4 & 311.7 & 284.1 \\
\hline $\begin{array}{l}\text { Parque Nacional } \\
\text { Queulat }\end{array}$ & PNQ & -44.40 & -72.42 & 101.7 & 1.5 & 1446 & 18 & 5 & 5 & 265.4 & 220.9 & 213.4 & 212.4 \\
\hline Cerro Hudson & $\mathrm{CH}$ & -46.08 & -72.93 & 22.3 & 0.9 & 1405 & 18 & 10 & 9 & 268.6 & 232.0 & 229.7 & 221.9 \\
\hline Cerro Erasmo & $\mathrm{CE}$ & -46.16 & -73.2 & 40.4 & 2.9 & 1375 & 21 & 7 & 7 & 181.2 & 151.5 & 144.1 & 141.0 \\
\hline $\begin{array}{l}\text { Northern Patagonia } \\
\text { Icefield }\end{array}$ & NPI & -47.01 & -73.5 & 781.7 & 1.0 & 1340 & 20 & 44 & 44 & 4635.7 & 4142.3 & 4070.2 & 3976.0 \\
\hline $\begin{array}{l}\text { Northern Patagonian } \\
\text { mountain glaciers }\end{array}$ & NPMG & -47.01 & -73.50 & 27.6 & 0.2 & 1471 & 22 & 25 & 25 & 251.0 & 186.3 & 178.3 & 176.1 \\
\hline Cordón la Parvas & CLP & -46.59 & -73.05 & 16.3 & 0.7 & 1483 & 27 & 16 & 16 & 125.8 & 93.7 & 88.4 & 85.6 \\
\hline $\begin{array}{l}\text { Cordillera Lago } \\
\text { General Carrera }\end{array}$ & CLGC & -46.83 & -73.07 & 33.0 & 1.4 & 1671 & 28 & 18 & 18 & 189.8 & 138.6 & 133.2 & 131.6 \\
\hline El Volcán & EV & -47.59 & -72.61 & 48.2 & 0.7 & 1521 & 21 & 40 & 36 & 511.8 & 387.1 & 361.9 & 354.3 \\
\hline Monte San Lorenzo & MSL & -47.59 & -72.37 & 48.7 & 2.6 & 1948 & 27 & 11 & 10 & 207.8 & 150.3 & 145.4 & 142.9 \\
\hline jierra de Sangra & SDS & -48.83 & -73.20 & 192.4 & 7.1 & 1579 & 23 & 7 & 6 & 363.7 & 294.2 & 290.3 & 271.3 \\
\hline ago del Desierto & LDP & -49.11 & -72.80 & 74.1 & 3.0 & 1403 & 22 & 2 & 2 & 137.8 & 137.8 & 137.8 & 77.1 \\
\hline Cerro Paine Grande & CPG & -50.90 & -73.20 & 22.2 & 1.5 & 1313 & 26 & 13 & 13 & 96.4 & 77.9 & 76.5 & 76.4 \\
\hline $\begin{array}{l}\text { Southern Patagonia } \\
\text { Icefield }\end{array}$ & SPI & -49.74 & -73.47 & 1343.9 & 0.2 & 1191 & 21 & 161 & 154 & 14862.1 & 13657.3 & 13424.0 & 13218.8 \\
\hline $\begin{array}{l}\text { Southern Patagonian } \\
\text { mountain glaciers }\end{array}$ & SPMG & -49.74 & -73.47 & 30.4 & 0.5 & 956 & 26 & 25 & 25 & 495.4 & 125.1 & 124.7 & 95.2 \\
\hline Torres del Paine & TDP & -51.42 & -73.14 & 11 & & 1093 & 20 & J & 5 & 70.0 & 28.0 & 27.0 & 26.8 \\
\hline Monte Burney & $\mathrm{MB}$ & -52.3 & -73.36 & 15.5 & 15.5 & 883 & 27 & 1 & 1 & 22.4 & 16.3 & 15.7 & 15.5 \\
\hline $\begin{array}{l}\text { Gran Campo Nevado } \\
\text { mountain glaciers }\end{array}$ & GCMG & -52.95 & -72.99 & 7.2 & 0.1 & 801 & 22 & 17 & 17 & 29.4 & 27.0 & 26.4 & 25.3 \\
\hline Gran Campo Nevado & $\mathrm{GCN}$ & -52.95 & -72.99 & 30.9 & 0.7 & 836 & 23 & 35 & 35 & 263.2 & 251.1 & 242.6 & 236.9 \\
\hline Isla Riesco & RI & -52.95 & -72.58 & 35.1 & 7.4 & 858 & 17 & 4 & 4 & 120.4 & 110.4 & 107.0 & 106.6 \\
\hline $\begin{array}{l}\text { Estrecho de } \\
\text { Magallanes }\end{array}$ & M & -53.79 & -72.58 & 180.5 & 180.5 & 717 & 14 & 1 & 1 & 187.9 & 183.4 & 182.1 & 180.5 \\
\hline Tierra del Fuego & TDF & -54.43 & -70.81 & 76.2 & 3.8 & 748 & 17 & 4 & 4 & 173.5 & 168.2 & 164.5 & 163.9 \\
\hline Monte Sarmiento & MS & -54.57 & -70.47 & 25 & 1.4 & 867 & 20 & 17 & 17 & 199.3 & 186.6 & 183.1 & 183.1 \\
\hline Cordillera Darwin & CD & -54.66 & -69.72 & 160.1 & 0.5 & 938 & 22 & 94 & 94 & 2138.1 & 1930.2 & 1855.2 & 1832.7 \\
\hline $\begin{array}{l}\text { Cordillera Darwin } \\
\text { mountain glaciers }\end{array}$ & CDMG & -54.66 & -69.72 & 10.4 & 0.4 & 801 & 21 & 30 & 30 & 119.3 & 102.8 & 99.0 & 98.9 \\
\hline Isla Hoste & $\mathrm{IH}$ & -55.22 & -69.6 & 93.3 & 0.5 & 727 & 19 & 18 & 18 & 243.5 & 228.8 & 221.5 & 220.8 \\
\hline Entire region & All & -48.58 & -73.45 & 1343.9 & 0.14 & 1172 & 22 & 640 & 626 & 26848.8 & 23743.1 & 23229.0 & 22717.5 \\
\hline
\end{tabular}

proportion of the glacierized area (8.3\%; Fig. 3c). Many of the valley or outlet glaciers have a compound basin (numerous cirques or catchment areas) or compound basins, where two compound basin drainage systems merge (Fig. 3d; Rau and others, 2005). The majority (526) of the glaciers surveyed terminate on land, although 100 have calving termini (35 marine and 65 lacustrine).

Mean glacier elevation ranged from $496 \mathrm{~m}$ a.s.I. (IH-14) to 2182 ma.s.l. (MSL-5) (Table 2). NPI-1 had the highest maximum elevation (3968 ma.s.I.). Overall, $41 \%$ of the glaciers had a median altitude of 1000-1500 ma.s.l., with only one glacier having a median altitude of $0-500 \mathrm{~m}$ or $>2000 \mathrm{~m}$ (Fig. 3e). There was a weak relationship $\left(r^{2}=0.2\right)$ between maximum altitude and glacier area in 2001
(Fig. 3f), and there was a trend towards decreasing glacier median altitudes southwards (Fig. 3g; Table 2). There was a large scatter in glacier altitude, with large outlet glaciers from the icefields having a wide range of median altitudes. Glacier slope varied with glacier length $\left(r^{2}=0.3\right.$; Fig. $\left.3 \mathrm{~h}\right)$, which is important, as shorter, steeper glaciers typically have the fastest response times (Raper and Braithwaite, 2009). Regionally, the steepest glaciers were found in Parque Nacional Vicente Pérez Rosales, and the lowest mean slopes were found in the NPI and SPI (Table 2).

The NPI $\left(4365 \mathrm{~km}^{2}\right)$ was $120 \mathrm{~km}$ long, $70 \mathrm{~km}$ at its widest, and extended from $46^{\circ} 30^{\prime} \mathrm{S}$ to $47^{\circ} 30^{\prime} \mathrm{S}$ (Fig. 2). It had a mean altitude of 1340 ma.s.l. We analysed 44 outlet glaciers of the NPI covering $3976 \mathrm{~km}^{2}$, and 

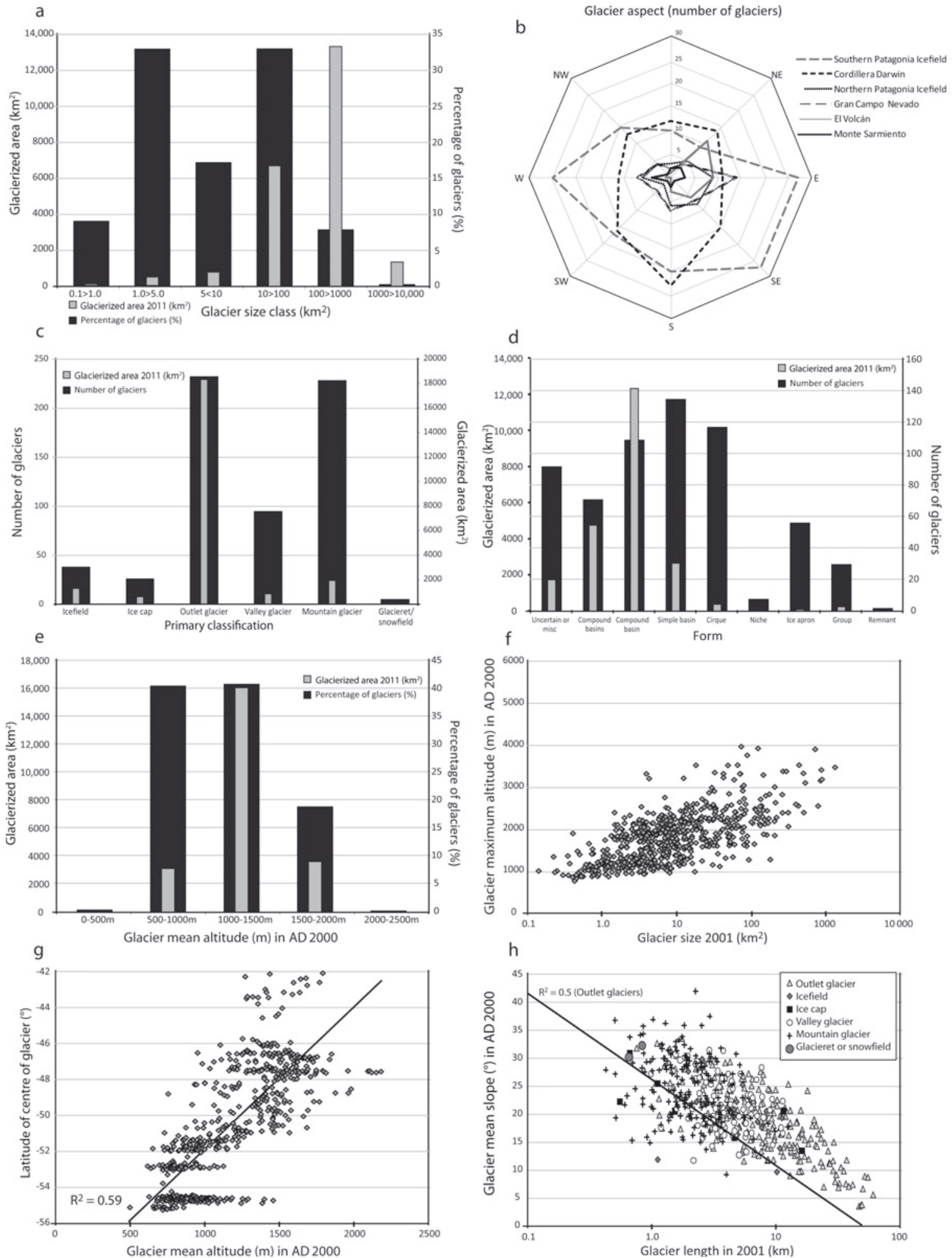

Fig. 3. (a) Glacierized area in 2011 and number of glaciers in each size class. (b) Glacier aspect for the main regions. (c) Number of glaciers in each 'Primary Classification' (from GLIMS protocols). (d) Numbers of glaciers in each category of the 'Form' attribute (from GLIMS protocols). (e) Mean altitude for glaciers across the study region. (f) Comparison between glacier area in 2001 and glacier maximum altitude, with regression line. Note logarithmic scale. (g) Relationship between glacier latitude and median altitude. (h) Relationship between glacier length and mean slope. Note logarithmic scale.

59 isolated nearby glaciers (in NPMG, Cordón La Parvas and Cordillera Lago General Carrera), covering $389 \mathrm{~km}^{2}$. These mountainous regions generally had glaciers with high mean slopes and altitudes (Table 2). Nineteen of the outlet glaciers had calving termini, of which only one (Glaciar San Rafael) was marine-terminating. Glaciers west of the ice divide made up the majority of the glacierized area of the NPI (Table 3; Fig. 4a). The more southerly glaciers of El Volcán (Fig. 1; Table 2) were primarily small ice caps and mountain glaciers with a mean altitude of $1521 \mathrm{~m}$ a.s.l., and all were land-terminating, though some had small lakes in their forefields. 


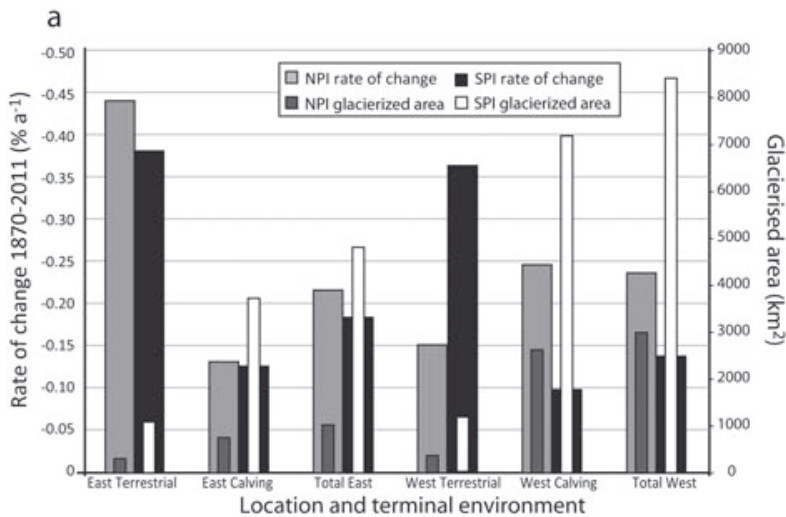

d

b
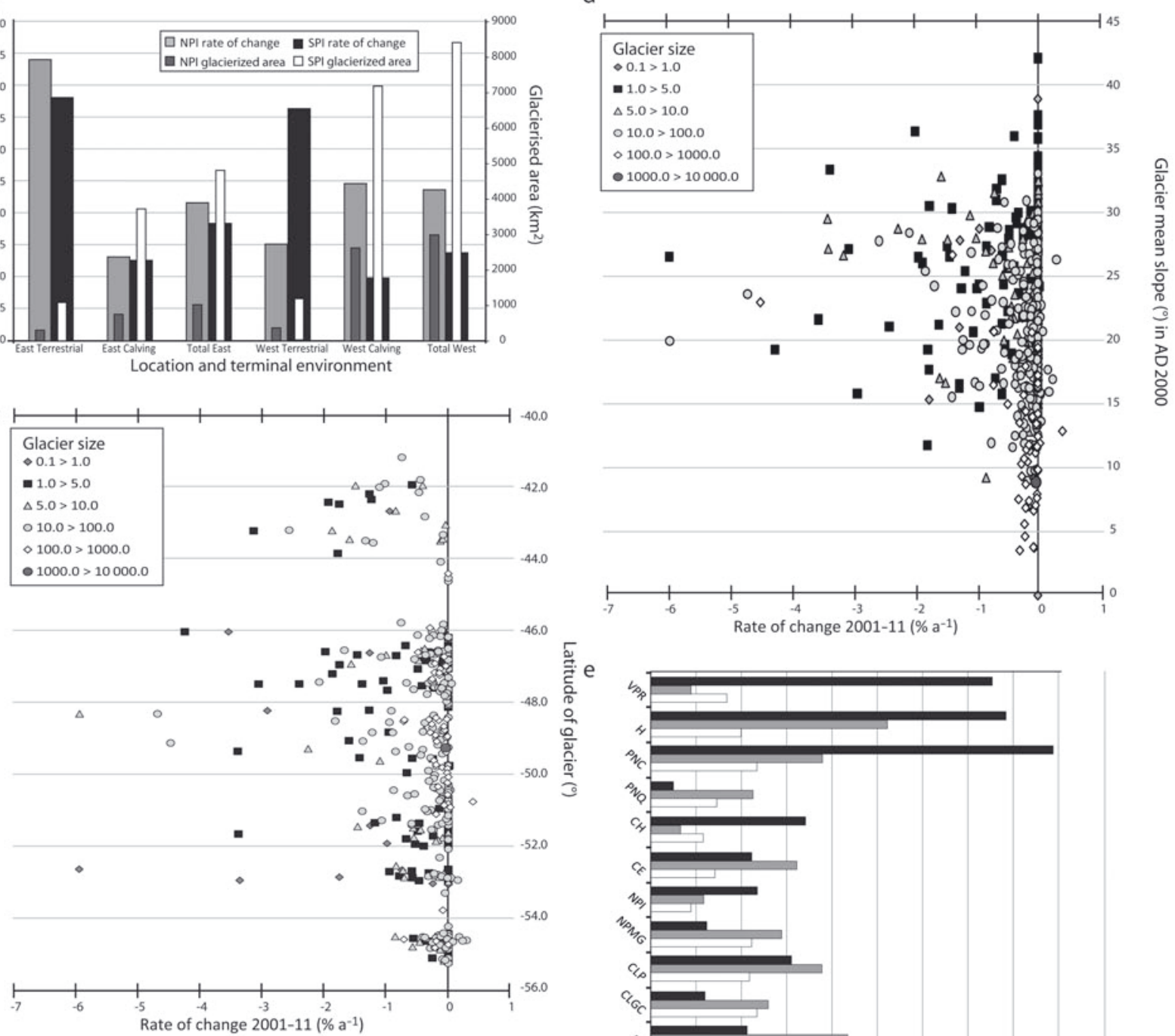


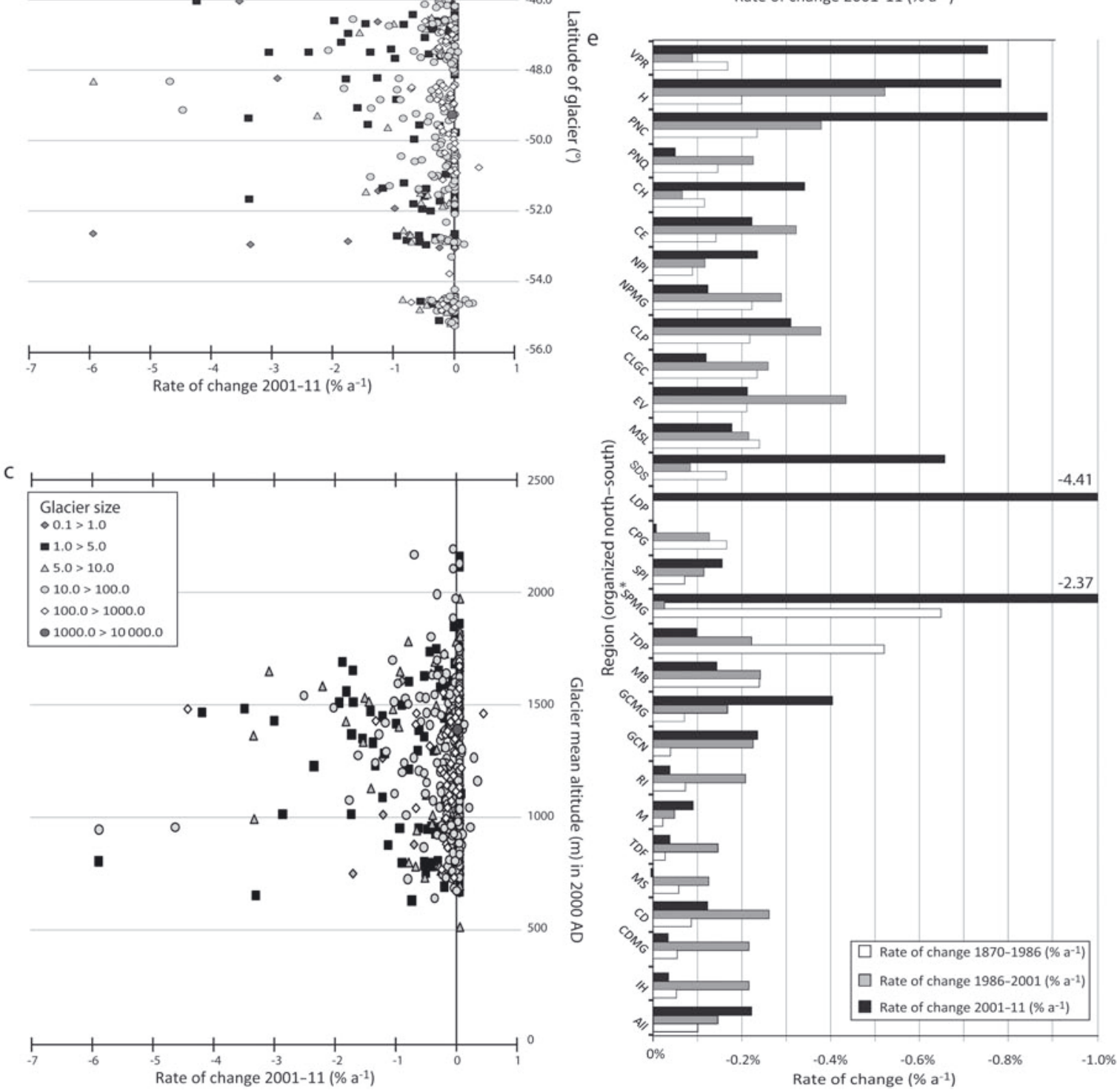

Fig. 4. (a) Glacierized area and rates of area loss for the NPI and SPI, with calving and land-terminating glaciers shown separately. (b) Rate of change 2001-11 against latitude, with glaciers divided into size classes. (c) Rate of glacier shrinkage 2001-11 against glacier mean altitude, with glaciers divided into size classes. (d) Rate of glacier shrinkage 2001-11 against glacier mean slope, with glaciers divided into size classes. (e) Rate of change for each region over three time periods. For Lago del Desierto (LDP) and Southern Patagonian mountain glaciers (starred), the anomalously high shrinkage rates are given in the figure. See Table 2 for abbreviations. 
Table 3. Glacier change for the NPI and SPI

\begin{tabular}{|c|c|c|c|c|c|c|c|c|c|}
\hline & \multirow[t]{3}{*}{ Ice divide } & \multirow[t]{3}{*}{ Number of glaciers } & \multirow{2}{*}{$\begin{array}{l}\text { Glacierized area } \\
2011\end{array}$} & \multicolumn{3}{|c|}{ Change } & \multicolumn{3}{|c|}{ Rate of change } \\
\hline & & & & 1870-1986 & 1986-2001 & $2001-11$ & 1870-1986 & 1986-2001 & $2001-11$ \\
\hline & & & $\mathrm{km}^{2}$ & $\%$ & $\%$ & $\%$ & $\% a^{-1}$ & $\% a^{-1}$ & $\% a^{-1}$ \\
\hline NPI & West & 19 & 2962.5 & -8.8 & -1.9 & -2.4 & -0.08 & -0.12 & -0.24 \\
\hline NPI & East & 25 & 1013.5 & -15.5 & -1.4 & -2.2 & -0.13 & -0.09 & -0.22 \\
\hline SPI & West & 73 & 8417.4 & -5.9 & -1.9 & -1.4 & -0.05 & -0.13 & -0.14 \\
\hline SPI & East & 81 & 4801.4 & -11.0 & -1.3 & -1.8 & -0.09 & -0.09 & -0.18 \\
\hline
\end{tabular}

The SPI was the largest icefield $\left(13219 \mathrm{~km}^{2}\right)$, and stretched north-south for $400 \mathrm{~km}$, from $48^{\circ} \mathrm{S}$ to $52^{\circ} \mathrm{S}$ along the southern Andes, with widths of $30-70 \mathrm{~km}$ and a mean altitude of $1191 \mathrm{~m}$ a.s.I. In our assessment, it was drained by 154 outlet and simple basin glaciers with 45 nearby isolated glaciers (in SPMG, Lago del Desierto, Cerro Paine Grande and Torres del Paine) covering $278 \mathrm{~km}^{2}$. Its area was again dominated by glaciers west of the ice divide (Table 3), but with several large outlet glaciers draining eastwards. Of the outlet glaciers, 54 had calving termini, and they accounted for $10945 \mathrm{~km}^{2}$, or $83 \%$ of the total area (Fig. $4 \mathrm{a}$ ).
GCN $\left(52^{\circ} 40^{\prime}-52^{\circ} 55^{\prime} \mathrm{S}\right)$ was the smallest ice cap $\left(262 \mathrm{~km}^{2}\right)$, with 35 glaciers (of which 4 calved into lakes), and was $24 \mathrm{~km}$ long and $16 \mathrm{~km}$ wide. It was surrounded by 17 small mountain glaciers and ice caps. Cordillera Darwin $\left(1931 \mathrm{~km}^{2}\right)$ was the southernmost icefield $\left(54^{\circ} 30^{\prime} \mathrm{S}\right)$ and was $90 \mathrm{~km}$ long and $30 \mathrm{~km}$ wide. There were 99 glaciers, of which 66 were outlet glaciers (covering $408 \mathrm{~km}^{2}$ ). Ten of these had calving termini. There were 18 small isolated glaciers nearby, including 7 valley glaciers, and there were 6 small icefields and ice caps nearby.

Table 4. Area change, percentage change and annual rates of change in each region and time period. $N$ refers to the number of glaciers shrinking fastest in this period. For region codes see Table 2

\begin{tabular}{|c|c|c|c|c|c|c|c|c|c|c|c|c|c|c|c|c|c|c|c|}
\hline \multirow[t]{3}{*}{ Region } & \multicolumn{4}{|c|}{ 1870-2011 } & \multicolumn{5}{|c|}{ 1870-1986 } & \multicolumn{5}{|c|}{ 1986-2001 } & \multicolumn{5}{|c|}{$2001-11$} \\
\hline & \multicolumn{2}{|c|}{ Area change } & \multicolumn{2}{|c|}{ Rate of change } & \multicolumn{2}{|c|}{ Area change } & \multicolumn{2}{|c|}{ Rate of change } & \multirow[t]{2}{*}{ N } & \multicolumn{2}{|c|}{ Area change } & \multicolumn{2}{|c|}{ Rate of change } & \multirow[t]{2}{*}{$N$} & \multicolumn{2}{|c|}{ Area change } & \multicolumn{2}{|c|}{ Rate of change } & \multirow[t]{2}{*}{ 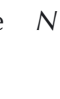 } \\
\hline & $\mathrm{km}^{2}$ & $\%$ & $k m^{2} a^{-1}$ & $\% a^{-1}$ & $\mathrm{~km}^{2}$ & $\%$ & $\mathrm{~km}^{2}$ & $\% a^{-1}$ & & $\mathrm{~km}^{2}$ & $\%$ & $n^{2} a^{-1}$ & $\% \mathrm{a}$ & & $\mathrm{km}^{2}$ & $\%$ & -1 & $\% a^{-1}$ & \\
\hline PR & -23.6 & -26.3 & -0.1 & -0.19 & -17.3 & -19.3 & -0.1 & -0.1 & 0 & -1.0 & -1.3 & -0.1 & -0.09 & 0 & -5.3 & -7.5 & -0.5 & -0.75 & \\
\hline & & -34.3 & -0.3 & 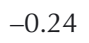 & & -22.7 & & & 0 & & -7.8 & & & & & -7.8 & & & \\
\hline $\mathrm{NC}$ & 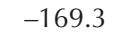 & -37.3 & -1.1 & -0.2 & -12 & -27.1 & & -0. & 1 & -18.8 & -5.7 & & & 3 & -2 & -8.8 & & & 2 \\
\hline 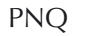 & & -20.0 & -0.4 & -0 & -4 & -16.8 & & -0 & 1 & -7.4 & -3.4 & & & 1 & & -0.5 & & & \\
\hline $\mathrm{CH}$ & & -17.4 & -0.3 & -0 . & -3 & -13.6 & 0.3 & -0 & 1 & -2.4 & -1.0 & -0.2 & -0 & 2 & -7.8 & -3.4 & .8 & & \\
\hline CE & -4 & -22.2 & -0.3 & -0 . & -2 & -16.4 & -0.3 & -0 . & 2 & -7.3 & -4.8 & -0.5 & -0 & 3 & -3.2 & -2.2 & 3 & & 2 \\
\hline & & -14.2 & -4.3 & -0.10 & -49 & -10.6 & 4 & -0 & 3 & -72.1 & -1.7 & -4.8 & & 6 & -94.1 & -2.3 & 4 & & 14 \\
\hline PMG & & -29.9 & -0.6 & -0 & -6 & -25.8 & & -0 & 13 & -8.0 & -4.3 & & & 0 & - & -1.2 & .2 & & \\
\hline 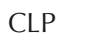 & -40 & -31.9 & -0.3 & -0 . & -3 & -25.6 & -0.3 & -0 & 4 & -5.3 & -5.6 & & & 6 & & -3.1 & & & 5 \\
\hline LGC & & -30.7 & -0.4 & -0 . & & -27.0 & & -0 & 8 & -5.4 & -3.9 & & & 7 & -1 & -1.2 & & & 3 \\
\hline EV & -15 & -30.8 & -1.1 & -0.22 & -12 & -24.4 & -1.1 & -0 . & 12 & -25.1 & -6.5 & & -0 & 18 & -7.7 & -2.1 & 8 & & 5 \\
\hline MSI & & -31.2 & -0.5 & -0 . & & -27.7 & -0 & -0 & 3 & -4.9 & -3.2 & & & - & -2.6 & -1.8 & & & 2 \\
\hline & & -25.4 & -0.6 & -0 . & & -19.1 & -0 & & 0 & & -1.3 & & & 2 & & -6.5 & & & 4 \\
\hline & & -44.1 & & & & 0.0 & & & & & 0.0 & & & 0 & & -44.1 & & & 2 \\
\hline & & -20.7 & - & -0 & -18.4 & -19.1 & & & 7 & 5 & -1.9 & & & 4 & -0.1 & -0.1 & 0 & & 0 \\
\hline & & -11.1 & -1 & -0 & -120 & -8.1 & & & 51. & & -1.7 & & & $39-$ & -20 & -1.5 & & & 59 \\
\hline & & -80.8 & & & -37 & -74.7 & & & 2 & & -0.4 & & & 0 & -29.5 & -23.7 & & & \\
\hline TD & & -61.7 & $-c$ & -0 & -4 & -60.0 & -0 & -0 & & 9 & -3 & -0.1 & & 1 & -0.3 & -1.0 & 0 & & 1 \\
\hline 4 & & -31.1 & -0.1 & -0 & & -27.5 & -0 & -0 & 0 & 6 & -3 & & & 1 & $-c$ & -1.4 & 0 & & 0 \\
\hline GC & & -13.9 & & -0 & & -8.0 & 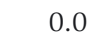 & -0 & 2 & -0.7 & -2.5 & .0 & -0 & S & -1.1 & -4.0 & 0.1 & & 4 \\
\hline GC & -2 & -10.0 & -0.1 & -0 & -1 & -4.6 & -0 & & 2 & -8.5 & -3.4 & & -0 & 11 & -5.6 & -2.3 & -0.6 & & 10 \\
\hline RI & -13.9 & -11.5 & -0.1 & -0 . & -10.1 & -8.4 & -0 & & 0 & -3.4 & -3.1 & & & 3 & -0.4 & -0.4 & 0.0 & & 1 \\
\hline$M$ & & -4.0 & & -0. & -4.6 & -2.4 & 0 & & 0 & -1.3 & -0.7 & -0.1 & & 0 & -1.6 & -0.9 & -0.2 & & 1 \\
\hline TD & & -5.5 & & & & -3.1 & & & 1 & -3.7 & -2.2 & & & 3 & -0.6 & -0.4 & -0.1 & & 0 \\
\hline MS & -16.2 & -8.1 & -0.1 & -0.06 & -12.7 & -6.4 & -0.1 & -0.05 & 5 & -3.5 & -1.9 & -0.2 & -0.12 & 8 & 0.0 & 0.0 & 0.0 & 00 & 2 \\
\hline$C D$ & -305.5 & -14.3 & -1.8 & -0.10 & -207.9 & -9.7 & -1.8 & -0.08 & 33 & -75.0 & -3.9 & -5.0 & -0.26 & 29 & -22.5 & -1.2 & -2.3 & -0.12 & 16 \\
\hline CDMG & -20.4 & -9.3 & $0 \Omega$ & -0.07 & -16.5 & -6.0 & 0.0 & -0.05 & 7 & -3.7 & -3.2 & 0.0 & -0.21 & 9 & -0.1 & -0.3 & 0.0 & -0.03 & 0 \\
\hline $\mathrm{IH}$ & -22.7 & -9.3 & -0.1 & -0.07 & -14.7 & -6.0 & -0.1 & -0.05 & 4 & -7.3 & -3.2 & -0.5 & -0.21 & 7 & -0.7 & -0.3 & -0.1 & -0.03 & 1 \\
\hline All & -4131.3 & -15.4 & -26.8 & -0.11 & -3105.6 & -11.6 & -26.8 & -0.10 & 180 & -514.1 & -2.2 & -34.3 & -0.14 & $183-$ & -511.5 & -2.2 & -51.2 & -0.22 & 165 \\
\hline
\end{tabular}

For the NPI, 20 glaciers shrank fastest between 1975 and 1986. 

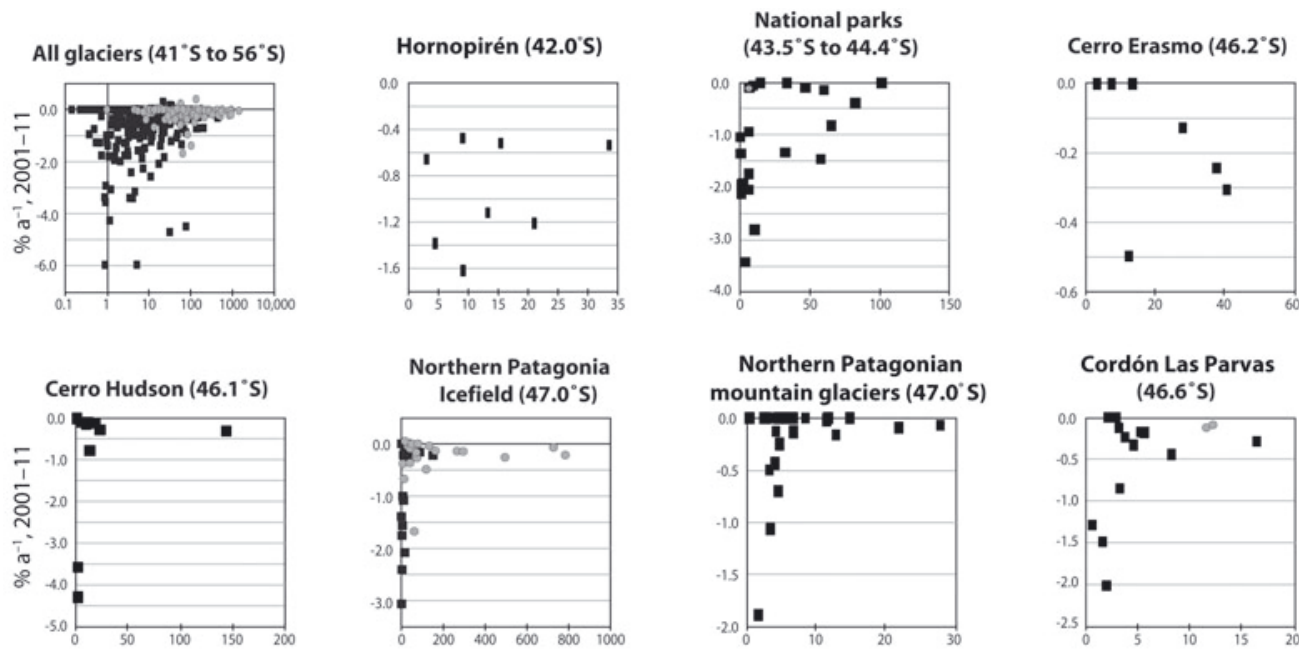

Northern Patagonian mountain glaciers $\left(47.0^{\circ} \mathrm{S}\right)$

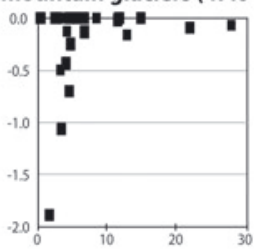

\section{Cordón Las Parvas} $\left(46.6^{\circ} \mathrm{S}\right)$
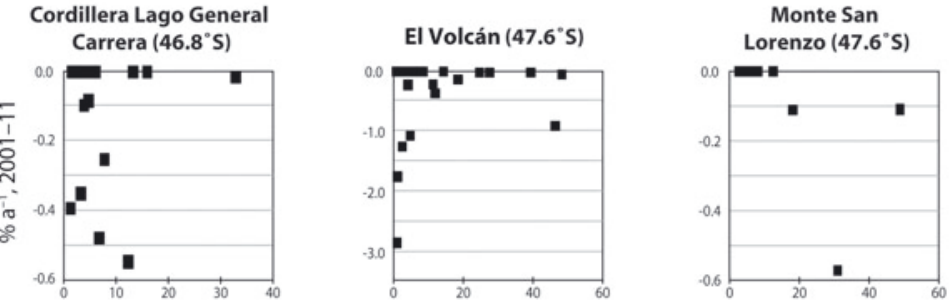

Southern Patagonia Icefield $\left(49.7^{\circ} \mathrm{S}\right)$

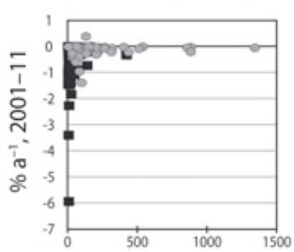

Cerro Paine Grande (50.9S)

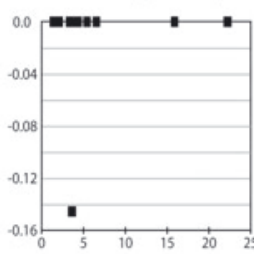

SPMG and Lago del Desierto $\left(49.74^{\circ} \mathrm{S}\right)$

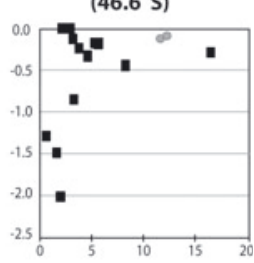

Sierra de Sangra $\left(48.8^{\circ} \mathrm{S}\right)$

Gran Campo Nevado $\left(53.0^{\circ} \mathrm{S}\right)$

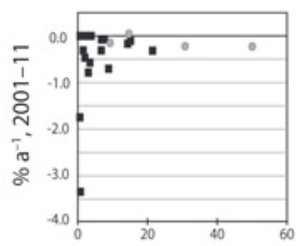

Gran Campo Nevado mountain glaciers $\left(53.0^{\circ} \mathrm{S}\right)$
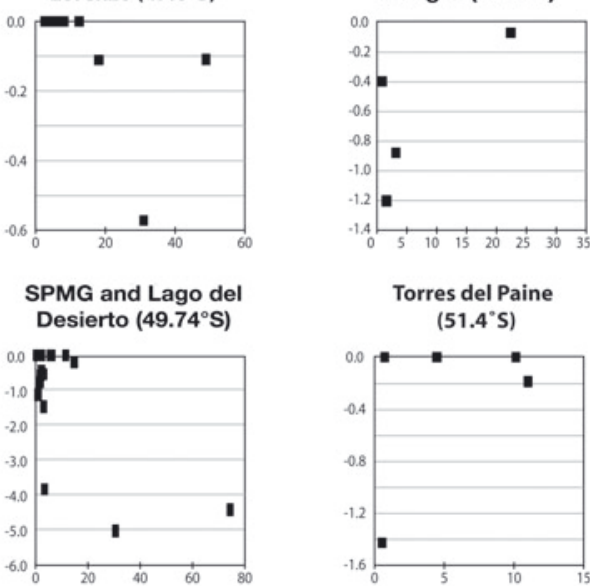

Torres del Paine (51.4 $\left.{ }^{\circ} \mathrm{S}\right)$

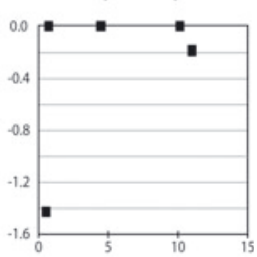

Isla Riesco $\left(53.0^{\circ} \mathrm{S}\right)$
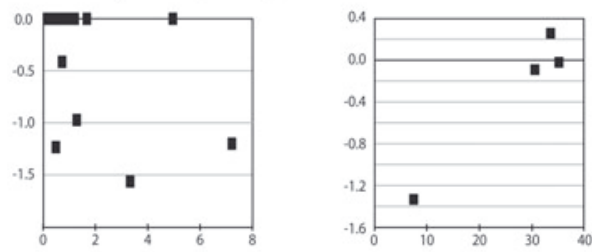

Tierre del

Fuego $\left(54.5^{\circ} \mathrm{S}\right)$

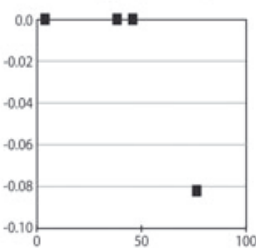

Cordillera Darwin Cordillera Darwin $\left(54.6^{\circ} \mathrm{S}\right)$ mountain glaciers $\left(54.7^{\circ} \mathrm{S}\right)$

Isla Hoste $\left(55.2^{\circ} \mathrm{S}\right)$
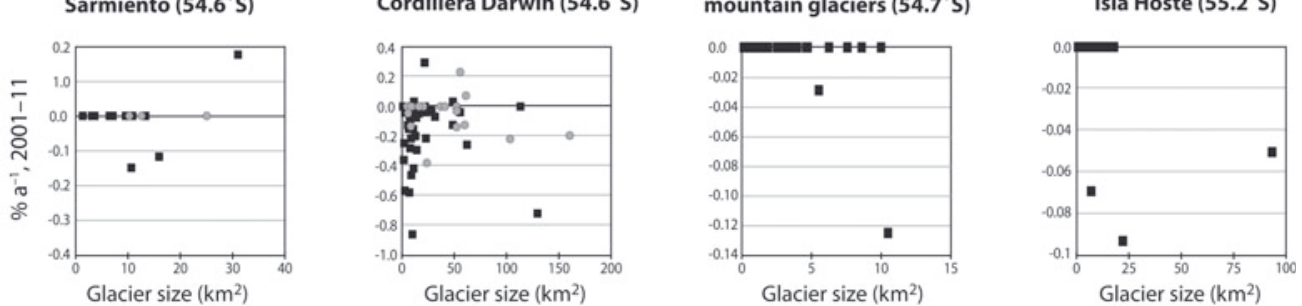

Fig. 5. Rate of annual change $\left(\% \mathrm{a}^{-1}\right)$ for 2001-11 against 2011 glacier size for each region. SPMG refers to isolated glaciers surrounding the SPI. 'National parks' includes Parque Nacional Vicente Pérez Rosales, Parque Nacional Corcovado and Parque Nacional Queulat. Grey circles denote calving glaciers; black squares denote land-terminating glaciers. Solid horizontal line is nil change; shrinkage is below this line, and advance is above. Latitude of regional centre is shown.

\subsection{Changes in glacier length and area from 1870 to 2011}

\subsubsection{General trends}

A total of 640 glaciers were digitized from 1870 from $40^{\circ} \mathrm{S}$ to $56^{\circ} \mathrm{S}$ (Figs 4-6; Table 4). Of these, 626 remained in 1986. Overall, $90.2 \%$ of the glaciers shrank between 1870 and
2011, 0.3\% advanced and 9.5\% showed no change. Despite some small advances, which are generally short-term and limited to tidewater glaciers, all regions have suffered extensive glacier surface area loss. For the SPI and eastern $\mathrm{NPI}$, the greatest rates of shrinkage were observed in landterminating glaciers (Fig. 4a). Glacier shrinkage from 2001 
a

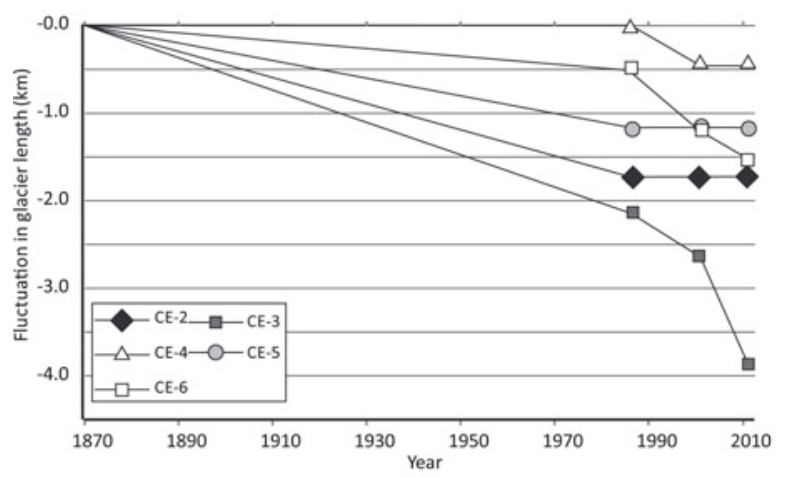

C

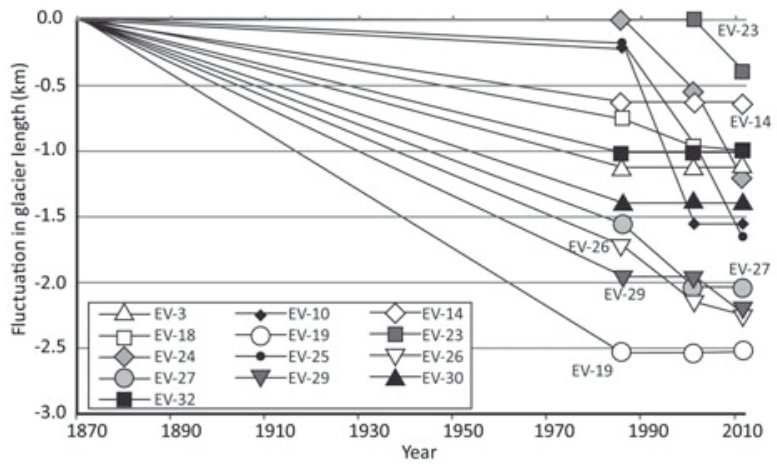

e

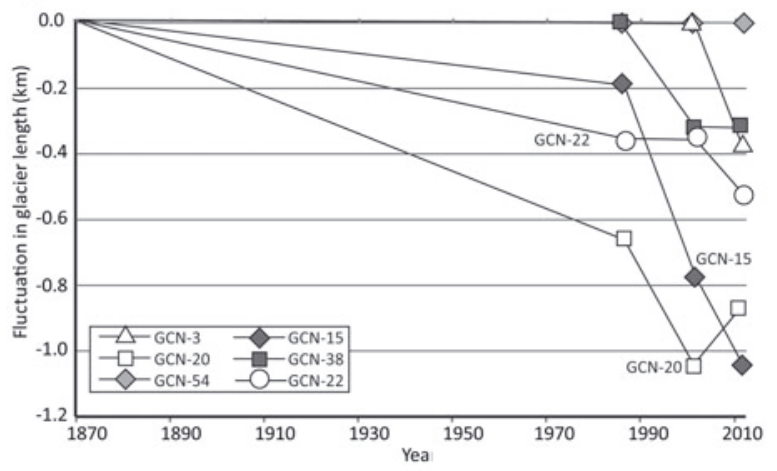

Land-terminating glacie

\section{b}

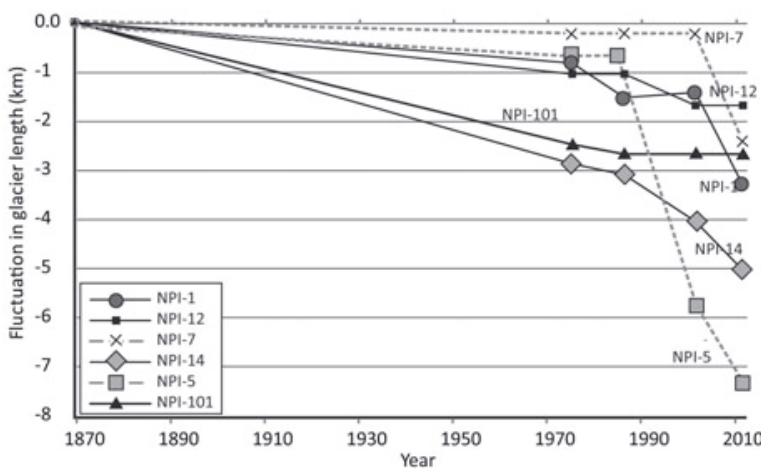

d

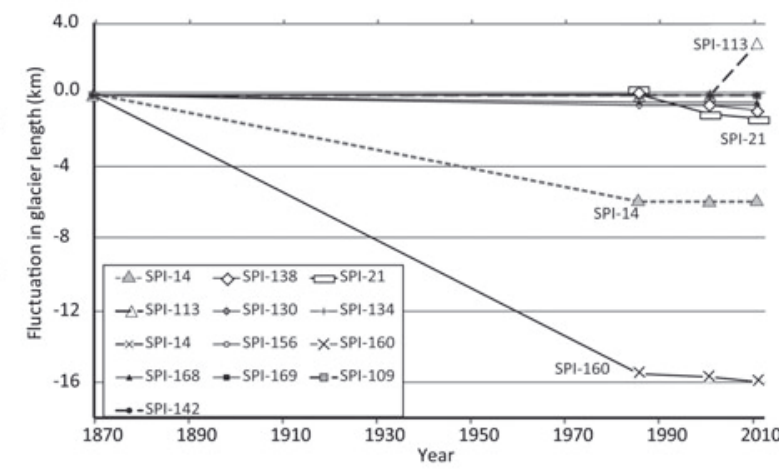

f

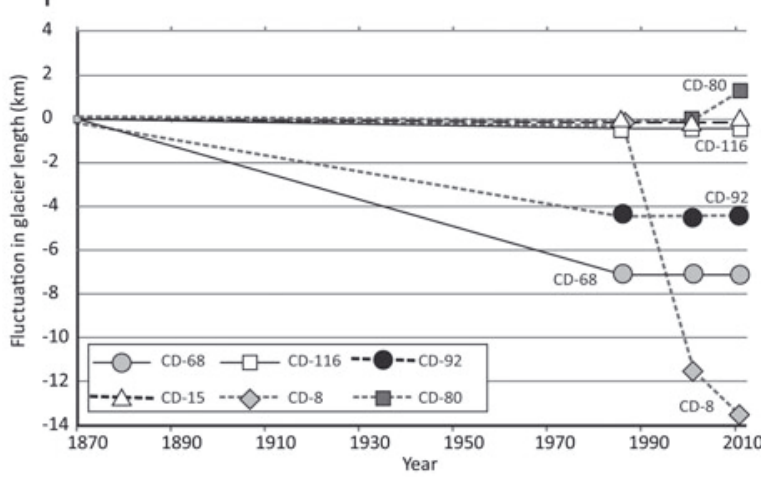

Marine-terminating glacier

Fig. 6. Graphs showing cumulative length changes for selected glaciers for key icefields. The black line indicates a glacier that terminates on land. The grey line with short dashes indicates lacustrine-terminating glaciers. The thick black dashed line indicates marine-terminating (tidewater) glaciers. (a) Cerro Erasmo; (b) the NPI; (c) El Volcán; (d) the SPI; (e) GCN; and (f) Cordillera Darwin.

to 2011 was greatest in glaciers less than $5 \mathrm{~km}^{2}$ in size, while those greater than $100 \mathrm{~km}^{2}$ had particularly slow rates of shrinkage (Fig. 4b). Rates of shrinkage were highest in the most northerly glaciers, with most glaciers shrinking. Latitudinal gradients are also emphasized, with nearly all glaciers from $41^{\circ} \mathrm{S}$ to $44^{\circ} \mathrm{S}$ shrinking, small glaciers from $44^{\circ} \mathrm{S}$ to $53^{\circ} \mathrm{S}$ also shrinking, and with little shrinkage in glaciers from $54^{\circ} \mathrm{S}$ to $56^{\circ} \mathrm{S}$ (Fig. 4b). Mean glacier altitude and slope (Fig. 4c and d) had little control on glacier shrinkage in Patagonia.

Annualized rates of shrinkage across South America increased for each time period measured (Table 4; Fig. 4e), with overall rates of shrinkage twice as rapid for 2001-11 as for $1870-1986\left(0.10 \% \mathrm{a}^{-1}\right.$ for $1870-1986,0.14 \% \mathrm{a}^{-1}$ for 1986-2001 and $0.22 \% \mathrm{a}^{-1}$ for 2001-11). Across the study area, percentage change per annum was greatest for 1870 1986 for 212 glaciers, for 1986-2001 for 172 glaciers and for 2001-11 for 155 glaciers. Across the study region, 14 glaciers extant during the LIA had disappeared entirely by 1986, mostly around the SPI.

\subsubsection{Mountain glaciers}

In general, rates of change were highest for 2001-11 in the more northerly locations (Parque Nacional Vicente Pérez Rosales, Hornopirén, Parque Nacional Corcovado, Cerro Hudson and SPMG; Figs 4e and 5), and for 1986-2001 in the more southerly locations (e.g. Cordillera Darwin, Isla Hosta, Monte Sarmiento, Isla Riesco and Tierra del Fuego; Fig. 1 for locations). North of $46^{\circ} \mathrm{S}$, most of the small, landterminating glaciers are rapidly shrinking, and the rate of area loss is accelerating (Figs 1, 4b and e and 5). Indeed, the ice caps of the Chilean Lake District experienced some of the highest rates of area loss in the area from 2001 to 2011 (Fig. 5; Table 4). Although there is little clear statistical 
relationship between glacierized area and rate of shrinkage, glaciers north of $52^{\circ} \mathrm{S}$ show increased relative rates of shrinkage. Of 16 glaciers in the Parque Nacional Corcovado, 11 shrank fastest from 2001 to 2011, 3 from 1986 to 2001, and 2 from 1870 to 1986 . These more northerly glaciers also tend to be higher, steeper and smaller (Figs $3 \mathrm{~g}$ and $4 \mathrm{~b}$ ), which may result in shorter response times.

Between $52^{\circ} \mathrm{S}$ and $46^{\circ} \mathrm{S}$, rates of area loss were also generally higher from 2001 to 2011, although with more variation. For the seven mountain glaciers of Cerro Erasmo, steady and accelerating glacier length recession was observed (Fig. 6a). All glaciers receded, but distances varied between 0.5 and $5.6 \mathrm{~km}$. Around the NPI, mountain glaciers receded rapidly between 1870 and 1986. For example, CLGC-6 receded $7.1 \mathrm{~km}\left(60 \mathrm{~m} \mathrm{a}^{-1}\right)$ during this period, but thereafter length did not change. Northern Patagonian mountain glaciers (NPMG) had a total area loss of $1.2 \%$ from 2001 to 2011, Cordón La Parvas mountain glaciers lost $3.2 \%$, and Cordillera Lago General Carrera glaciers lost $1.2 \%$ (Table 4).

Length fluctuations of 32 glaciers were measured for El Volcán. Some glaciers receded rapidly from 1870 to 1986 but have since remained stable (e.g. EV-14 $\left(0.6 \mathrm{~km}\right.$, or $\left.5 \mathrm{~m} \mathrm{a}^{-1}\right)$, EV-19 $\left(2.5 \mathrm{~km}\right.$, or $\left.22 \mathrm{~m} \mathrm{a}^{-1}\right)$, EV-30 $\left(1.4 \mathrm{~km}\right.$, or $\left.12 \mathrm{~m} \mathrm{a}^{-1}\right)$ and EV-32 $\left(1.0 \mathrm{~km}\right.$, or $\left.\left.9 \mathrm{~m} \mathrm{a}^{-1}\right)\right)$, but most have steadily receded (Fig. 6c). The glaciers that receded fastest were EV-37 $\left(63 \mathrm{~m} \mathrm{a}^{-1}\right.$ from 1986 to 2001), EV-22 (118 $\mathrm{m} \mathrm{a}^{-1}$ from 2001 to 2011), EV-24 (66 $\mathrm{ma}^{-1}$ from 2001 to 2011) and EV-28 (22 $\mathrm{m} \mathrm{a}^{-1}$ from 1870 to 1986). Rates of area loss peaked from 1986 to 2001 and then declined (Table 4).

For SPI mountain glaciers, the largest areal changes from 2001 to 2011 were for SPMG-5 (-3.83\%), SPMG-15 $(-5.03 \%)$, SPMG-7 $(-1.12 \%)$ and EC-1 (-4.41\%). Glaciers around the SPI, particularly south and east of the main icefield, shrank very rapidly after 2001 (Fig. 4e). From 2001 to 2011, the Lago del Desierto region had a reduction in glacier area of $44 \%$, SPMG of $26.8 \%$ and Lago del Desierto of $6.5 \%$ (Table 4 ). For these regions, rates of area change are several orders of magnitude greater after $2001\left(2.37 \% \mathrm{a}^{-1}\right.$ for SPMG) compared with 1870-1986. However, the mountains of El Cóndor are heavily snow-covered, which may induce an overestimation of glacierized area in 2001. There are also no trimlines or moraines mapped in this region, so LIA extents cannot be estimated.

Between $52^{\circ} \mathrm{S}$ and $54^{\circ} \mathrm{S}$ there is more variation, with GCN mountain glaciers shrinking fastest after 2001, while the Monte Burney ice cap and Isla Riesco glaciers shrank fastest from 1986 to 2001 (Fig. 4e). From 2001 to 2011, only two mountain glaciers around GCN shrank, with the other glaciers remaining stationary (Fig. 5). In Isla Riesco from 2001 to 2011, one glacier advanced (RI-1;0.26\% $\mathrm{a}^{-1}$ ) and only one shrank significantly (RI-4; $1.33 \% \mathrm{a}^{-1}$ ). Mountain glaciers south of $54^{\circ} \mathrm{S}$ (Tierra del Fuego, Monte Sarmiento, Cordillera Darwin mountain glaciers and Isla Hoste) generally shrank fastest from 1986 to 2001, and show little change since 2001 (cf. Figs 4e and 5).

\subsubsection{Northern Patagonia Icefield (NPI)}

Almost all glaciers (98.1\%) in the NPI shrank between 1870 and 2011. Length fluctuations were measured for $38 \mathrm{NPI}$ glaciers, and showed a general trend of increasing recession (Fig. 6b). Several glaciers were stable from 1986 to 2001, but receded from 2001 to 2011 (e.g. NPI-21 (Pared Norte; $112 \mathrm{ma}^{-1}$ ), NPI-20 (Pared Sur; $189 \mathrm{ma}^{-1}$ ) and NPI-2 $\left.\left(112 \mathrm{~m} \mathrm{a}^{-1}\right)\right)$. Still others receded at steadily increasing rates (e.g. NPI-10 (Strindberg) and NPI-14). NPI-7 (San Rafael; lagoonal) receded by $9.6 \mathrm{~km}\left(83 \mathrm{~m} \mathrm{a}^{-1}\right)$ between 1870 and 1986 , and by a further $1.2 \mathrm{~km}$ by 1990 , whereupon the margin stabilized.

The highest rates of shrinkage east of the NPI ice divide were for land-terminating glaciers. West of the ice divide, the highest rates of shrinkage were observed in calving glaciers, which also occupy a larger area (Fig. 4a). The large areal losses of the NPI from 1870 to 2011 were dominated by a small number of large glaciers. These include NPI-7 (San Rafael; 11.5\%), NPI-8 (San Quintin; 14.6\%) and NPI-25 (Colonia; $12.9 \%$ ) (Fig. 2). Glaciers east of the ice divide shrank by $2.2 \%$ from 2001 to 2011 (Table 3), compared with $2.4 \%$ for glaciers to the west. Four glaciers had small, shortterm advances (NPI-14 from 1975 to 1986; NPI-32 from 1986 to 2001; NPI-18 and NPI-86 from 2001 to 2011).

Overall, annual rates of area loss for 2001-11 $\left(0.23 \% \mathrm{a}^{-1}\right)$ were twice as high as those for 1870-1986 $\left(0.09 \% \mathrm{a}^{-1}\right)$ (Fig. 4e), with similar rates both west and east of the ice divide (Table 3). However, more glaciers shrank fastest from 1975 to 1986 than from 2001 to 2011 (Table 4). The rapid 2001-11 areal shrinkage of NPI-1 (Grosse; $1.69 \% \mathrm{a}^{-1}$ ), NPI-6 (Gualas; $0.97 \% \mathrm{a}^{-1}$ ), NPI-16 (HPN-4; 0.26\% $\mathrm{a}^{-1}$ ) and NPI-25 (Colonia; $0.15 \% \mathrm{a}^{-1}$ ) dominates the trend observed in Figure $4 \mathrm{e}$, but in general, the small glaciers fringing the icefield shrank fastest (Figs 4, 5 and 6a). The period of most rapid shrinkage of the other glaciers varies, from 1870-1986 (e.g. NPI-7 (San Rafael; 0.09\% $\mathrm{a}^{-1}$ )) to 1975-86 (e.g. NPI-8 (San Quintin; $\left.0.23 \% \mathrm{a}^{-1}\right)$ ) to $1986-2001$ (e.g. NPI-14 $\left(0.23 \% \mathrm{a}^{-1}\right), \mathrm{NPI}-12$ (Benito; $0.33 \% \mathrm{a}^{-1}$ ) and NPI-5 (Reicher; $\left.0.77 \% \mathrm{a}^{-1}\right)$ ) (Figs $2 \mathrm{~b}$ and $\mathrm{c}$ and $7 \mathrm{a}$ ). It is also clear from the scatter plots in Figure 5 that calving glaciers are currently shrinking less rapidly (as a percentage of their area per annum) than land-terminating glaciers. Indeed, Figure 4a shows that land-terminating glaciers have relative rates of area loss much higher than calving glaciers, both east and west of the ice divide, with land-terminating glaciers east of the ice divide shrinking at $0.27 \% \mathrm{a}^{-1}$ from 2001 to 2011, compared with $0.11 \% \mathrm{a}^{-1}$ for calving glaciers. However, it should be noted that these large calving glaciers have lost the most area in absolute terms and are still shrinking rapidly.

\subsubsection{Southern Patagonia Icefield (SPI)}

For the SPI, $96.5 \%$ of the glaciers shrank between 1870 and 2011, with the majority (59 of 154) shrinking fastest from 2001 to 2011. The length fluctuations of 157 glaciers show large but variable linear recession from their LIA maxima (e.g. SPI-14 (O'Higgins; $16.0 \mathrm{~km}$ by 2011; lacustrine) and SPI-1 (Jorge Montt; $10.0 \mathrm{~km}$ by 2001 followed by a small 2001-11 advance of $0.5 \mathrm{~km})$ ). Several large glaciers shrank particularly fast between 2001 and 2011 (e.g. SPI-142 (Occidental; $\left.216 \mathrm{ma}^{-1}\right), \operatorname{SPI}-179\left(76 \mathrm{~m} \mathrm{a}^{-1}\right)$ and SPI-22 $\left.\left(157 \mathrm{~m} \mathrm{a}^{-1}\right)\right)$ (Fig. 6d).

The largest relative area changes (1870-2011) were generally from the smaller outlet glaciers, such as SPI-26 $(82.4 \%)$, SPI-177 (85.8\%) and SPI-169 (93.2\%). The larger outlet glaciers have also lost surface area from 1870 to 2011 (e.g. from SPI-1 (Jorge Montt; 12.6\%), SPI-14 (O'Higgins; 10.9\%), SPI-31 (Upsala; 19.7\%) and SPI-142 (Occidental; $11.5 \%)$ ). Three glaciers advanced from 1986 to 2001 (SPI$137\left(2.1 \mathrm{~km}^{2}\right)$, SPI-198 $\left(2.4 \mathrm{~km}^{2}\right)$ and SPI-77 $\left.\left(0.3 \mathrm{~km}^{2}\right)\right)$ and three from 2001 to 2011 (SPI-113 $\left(4.9 \mathrm{~km}^{2}\right), \mathrm{SPI}-109$ $\left(0.6 \mathrm{~km}^{2}\right)$ and SPI-45 $\left.\left(4.9 \mathrm{~km}^{2}\right)\right)$; in the case of SPI-113, the 
Northern Patagonia Icefield (NPI)

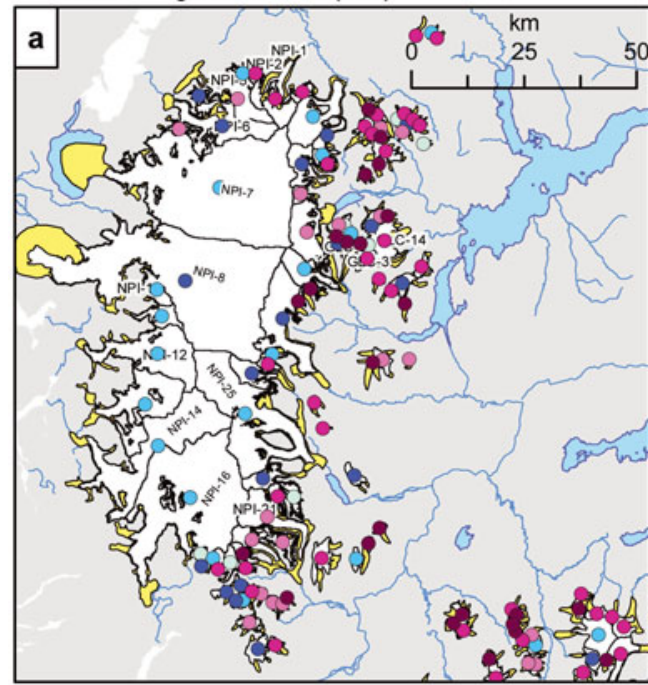

Gran Campo Nevado (GCN)

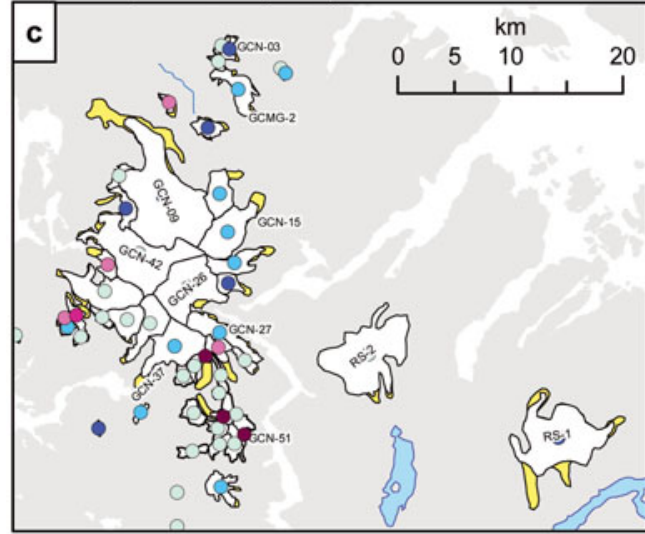

Cordillera Darwin (CD)

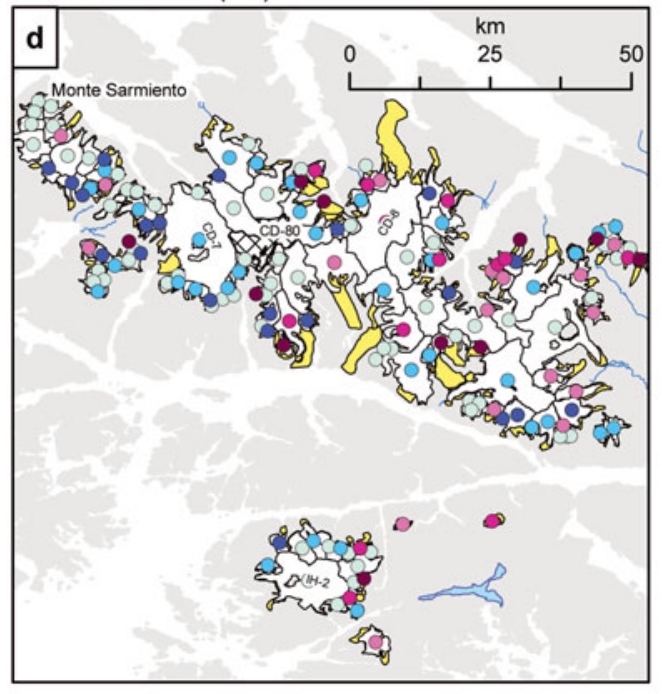

Southern Patagonia Icefield (SPI)

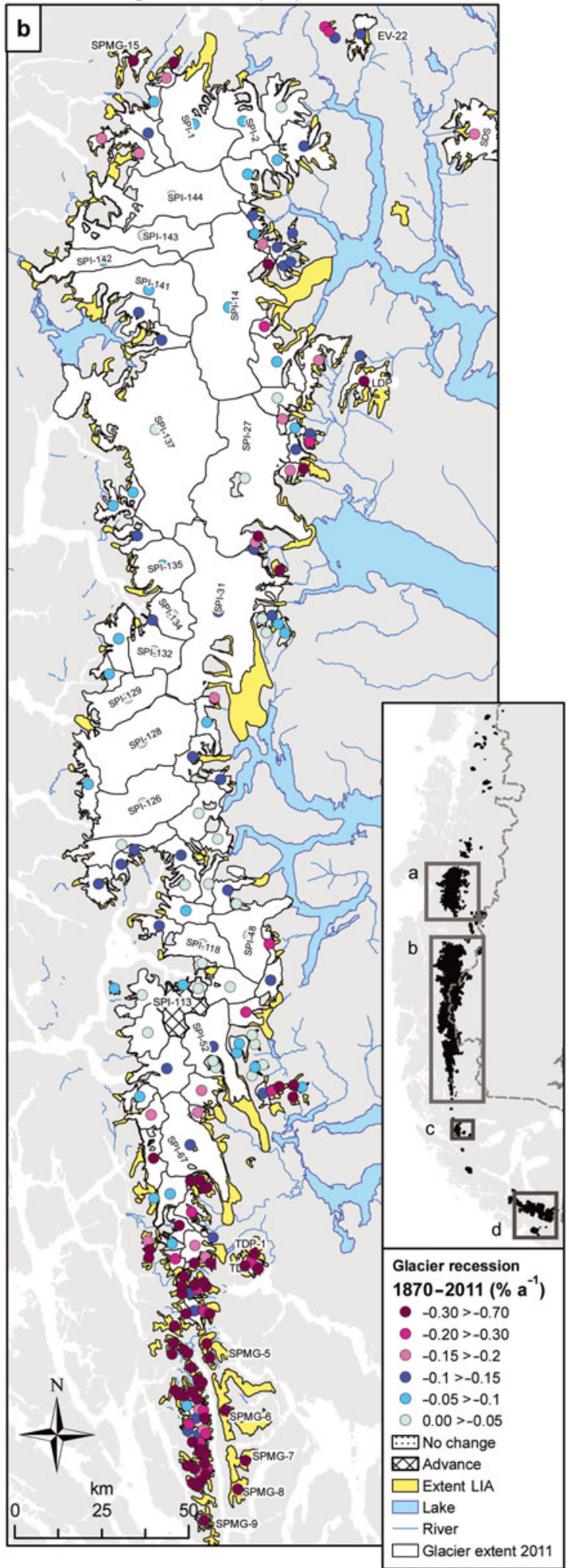

Fig. 7. Map of key icefields showing overall glacier shrinkage, 1870-2011. Glacier extent in 1870 is shown in white. Lakes larger than $15 \mathrm{~km}^{2}$ are also shown.

advance from 2001 to 2011 was beyond 1870 limits. However, it is difficult to determine the 1870 limit for fjordtype glaciers without moraines (e.g. SPI-113).

Overall, annual rates of shrinkage for the SPI were more than twice as rapid for $2001-11\left(0.15 \% \mathrm{a}^{-1}\right)$ as for 1870 $1986\left(0.07 \% \mathrm{a}^{-1}\right.$; Fig. 4e), but this result is again dominated by a small number of outlet glaciers (Figs 5 and 6b), particularly those south of the main icefield, such as SPI-70 $\left(1.22 \% \mathrm{a}^{-1}\right)$, SPI-149 $\left(6.37 \% \mathrm{a}^{-1}\right)$ and SPI-199 $\left(1.95 \% \mathrm{a}^{-1}\right)$ (Figs 6 and 7b). Although some calving outlet glaciers are shrinking rapidly (e.g. SPI-141 $\left(0.22 \% \mathrm{a}^{-1}\right), \mathrm{SPI}-145$ $\left(1.02 \% \mathrm{a}^{-1}\right)$ and SPI-31 (Upsala; $\left.19.7 \% \mathrm{a}^{-1}\right)$ ), in general, small, land-terminating glaciers are experiencing the highest annual rates of shrinkage (Figs 5 and 6). Across the SPI, 

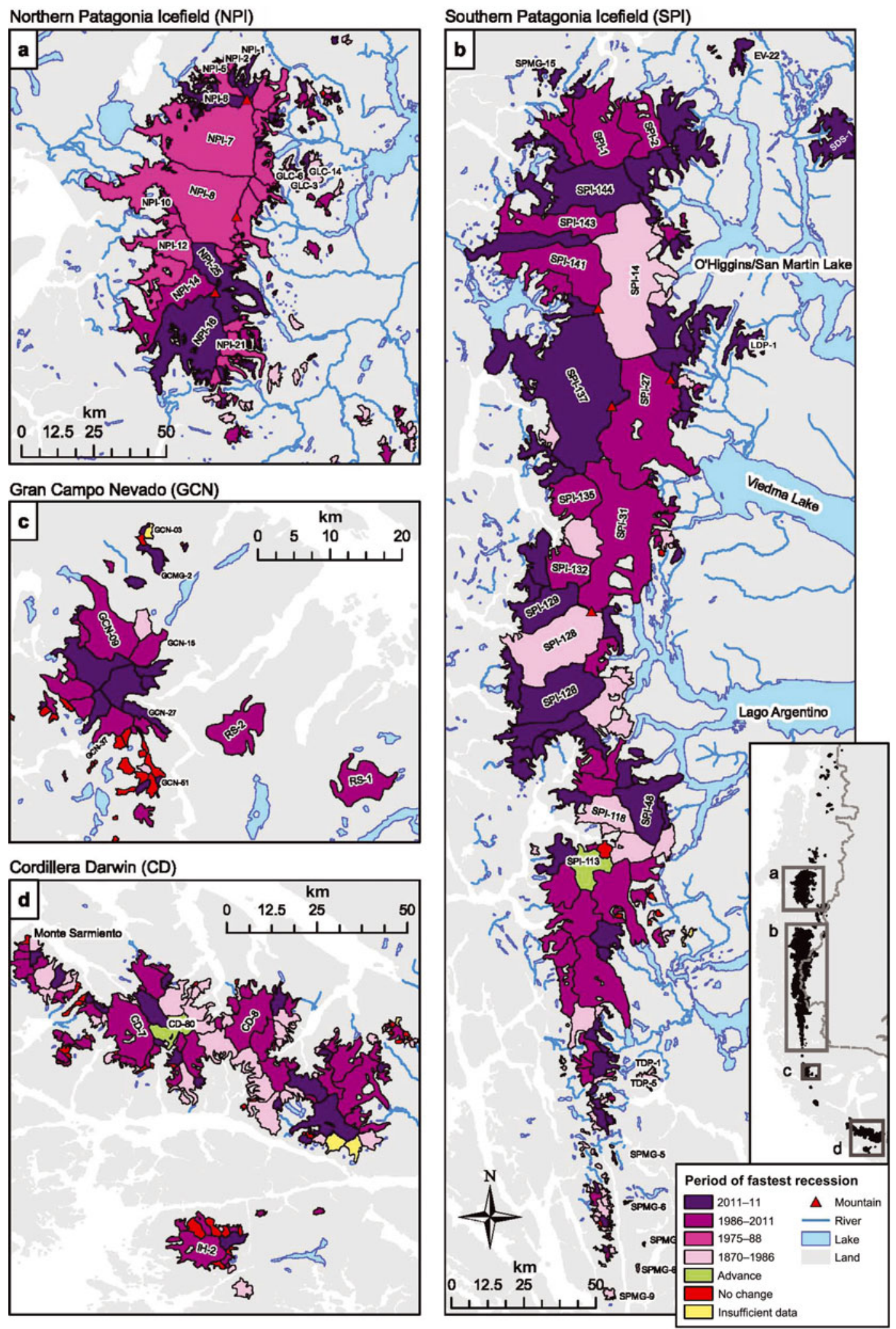

Fig. 8. Map of key icefields, illustrating period of fastest shrinkage. Glaciers in dark purple shrank fastest between 2001 and 2011 , light purple between 1986 and 2001, bright green between 1975 and 1986, and light green between 1870 and 1986. Glaciers in red advanced and glaciers in orange did not change. Glacier outlines are from 2011. Lakes larger than $15 \mathrm{~km}^{2}$ are also shown.

glaciers on the east of the ice divide had slightly higher annual rates of shrinkage (Table 3), with land-terminating glaciers shrinking at rates of $0.29 \% \mathrm{a}^{-1}$ from 2001 to 2011 , compared with $0.08 \% \mathrm{a}^{-1}$ for calving glaciers west of the ice divide (Fig. 4a). Figure $7 \mathrm{~b}$ illustrates the highly variable but rapid area loss in small glaciers around the fringes of the SPI, with particular large glaciers also losing surface area. Rates of area loss are increasing around the SPI, with most glaciers experiencing their highest rates of area loss from 2001 to 2011 (Fig. 8b; Table 4). For most of the remaining glaciers, the period of fastest area loss was 1986-2001. 


\subsubsection{Gran Campo Nevado (GCN)}

Around the GCN, 19 glaciers (36.5\%) exhibited no change, $33(63.5 \%)$ shrank and none advanced from 1870 to 2011. The 31 glaciers of GCN for which length was measured show, in general, recession, with various glaciers receding at different rates during each time period (Fig. 6e). While the mountain glaciers around GCN shrank rapidly after 2001, rates of area loss for land-terminating outlet glaciers have remained steady (Fig. 4e). Although most glaciers shrank from their LIA maxima, the highest annual rates of shrinkage were observed in small glaciers (Figs 5 and 6c). In total, 11 glaciers shrank fastest from 1986 to 2001, and 10 from 2001 to 2011 (Table 4). Annual rates of shrinkage were similar from 1986 to $2011\left(0.23 \% \mathrm{a}^{-1}\right.$; Table 4; Figs 4e and 8c). The glaciers losing area fastest from 2001 to 2011 were GCN-03 $\left(2.22 \% \mathrm{a}^{-1}\right)$, GCN-27 $\left(1.17 \% \mathrm{a}^{-1}\right)$ and GCN-51 $\left(5.53 \% \mathrm{a}^{-1}\right)$. The large outlet glaciers had smaller rates of relative annual area loss (e.g. GCN-26 $\left(0.53 \% \mathrm{a}^{-1}\right)$ and GCN-42 $\left.\left(0.37 \% \mathrm{a}^{-1}\right)\right)$ (Fig. 7c).

\subsubsection{Cordillera Darwin}

The numbers of shrinking glaciers in Cordillera Darwin fell from $77.5 \%$ for $1870-1986$, to $39.5 \%$ for $1986-2001$, to $31.8 \%$ for $2001-11$, with many glaciers showing no change from 2001 to 2011. Glacier length was measured for 107 glaciers in Cordillera Darwin, with most receding until 1986, and with little frontal change after this. Some calving glaciers had small advances between 1986 and 2011 (e.g. CD-80 (1.3 km from 2001 to 2011; further than its 1986 limit)). A lack of moraines makes the 1870 limit difficult to map. In contrast, CD-8, also marine-terminating, receded rapidly from 1986 to $2001\left(756 \mathrm{~m} \mathrm{a}^{-1}\right)$, after which recession slowed (202 $\mathrm{m} \mathrm{a}^{-1}$ from 2001 to 2011) (Fig. 6f).

Many glaciers had little or no shrinkage from 1870 to 2011, and the glaciers with the highest annual rates were small and land-terminating (Figs 5 and 7c). Outlet glaciers of Cordillera Darwin had their highest rates of area loss from 1986 to 2001 (Figs 4e and 8d). Overall, rates of area loss were more than twice as high for 1986-2001 $\left(0.26 \% \mathrm{a}^{-1}\right)$ as for $1870-1986\left(0.08 \% \mathrm{a}^{-1}\right)$, but shrinkage rates fell to $0.12 \% \mathrm{a}^{-1}$ after 2001 (Table 4; Fig. 4e). The number of glaciers that shrank fastest from 1986 to 2001 was 29, compared with 16 from 2001 to 2011 (Table 4).

The outlet glaciers of the nearby Monte Sarmiento and Isla Hoste ice caps show similar patterns, frequently with low rates of shrinkage (Figs 5 and 7d). Overall, for both ice caps, the period of fastest area loss was 1986-2001, with many glaciers having no observable change after 2001 (Figs 5 and 8d; Table 4). It is again the small, landterminating glaciers that are shrinking fastest (cf. Fig. 5).

\section{DISCUSSION}

\subsection{Comparison with previous inventories}

Our calculated area for the NPI of $3976 \mathrm{~km}^{2}$ in 2011 and $4070 \mathrm{~km}^{2}$ in 2001 is similar to the previous estimate of a total ice area of $3953 \mathrm{~km}^{2}$ in 2001 made by Rivera and others (2007). Our calculated area for the contemporary SPI of $13219 \mathrm{~km}^{2}$ in 2011 also fits with the previous estimate for this icefield of $13000 \mathrm{~km}^{2}$ (Aniya, 1999). For GCN, our calculated area of $243 \mathrm{~km}^{2}$ in 2001 fits well with the calculated area of Schneider and others (2007) of $252.6 \mathrm{~km}^{2}$ in 2002. Differences may be because we included more of the surrounding glaciers in our study.
Our data lend independent support to the assertion of Rignot and others (2003) and Glasser and others (2011) that the Patagonian icefields are shrinking at an increasing rate. Our calculated rates of area loss from the NPI suggest that there was an increase in annual area loss rates from $0.09 \% \mathrm{a}^{-1}$ in the 116 years between AD 1870 and 1986, to $0.12 \% \mathrm{a}^{-1}$ in the 15 years between 1986 and 2001, to $0.23 \% \mathrm{a}^{-1}$ from 2001 to 2011 (Table 4).

\subsection{Calving dynamics and asynchronous glacier change}

The acceleration in relative rates of area loss for the NPI from 2001 to 2011 was dominated by the smaller land-terminating glaciers (Figs $4 \mathrm{e}$ and 5). The shrinkage of marine- and lacustrine-terminating glaciers is highly variable, and reflects a dynamic and nonlinear response to multiple factors. For example, NPI-1, NPI-6, NPI-16 and NPI-25 terminate in freshwater lakes, and had particularly rapid rates of area loss. NPI-1, however, ablates not by calving but by rapid thinning and surface melting, with large supraglacial ponds (personal communication from M. Aniya, 2012). The fragmented snout of NPI-16 is difficult to define, which may induce an error in assessing the shrinkage. Supraglacial debris cover insulates the glacier from solar radiation and so affects ablation rates (Scherler and others, 2011). For example, slow shrinkage of NPI-1 (Glaciar Grosse) prior to 2001 was attributed to insulation by thick debris cover (Aniya, 2001). The floating terminus of NPI-6 (Glaciar Gualas) advanced from 1996 to 1999, possibly as a result of stretching (Aniya, 2001). This stretching was followed by more rapid shrinkage from 2001 to 2011, driven by rapid calving induced by large, deep, water-filled crevasses.

NPI-7 (Glaciar San Rafael), NPI-8 (Glaciar San Quintin) and NPI-5 (Glaciar Reicher) (Figs 2, 7 and 8) shrank most rapidly from 1870 to 1986, 1986 to 2001 and 1986 to 2001 respectively. These lacustrine-terminating glaciers are the largest of the NPI and have widely different accumulationarea ratios. They have shown repeated stillstands, advances and retreats since the 1920s (Winchester and Harrison, 1996; Aniya, 2007, Araneda and others, 2007; Lopez and others, 2010). Glaciar San Rafael currently has a high velocity and is thinning extensively (Willis and others, 2011). Steady thinning of the glacier surface could induce periodic flotation and rapid retreat, followed by grounding and stabilization (Aniya, 2007). An advance reported from 1992 to 1999 for Glaciar San Rafael (Aniya, 2001) explains the reduced area loss rates observed from 1986 to 2001. Glaciar San Quintin terminated on land until 1991, when shrinkage led to the formation of a lake in the former glacier basin, into which it now calves (Rivera and others 2007; Willis and others, 2011). Large-scale shrinkage was observed in Glaciar Reicher from 1996 to 1999 (Aniya, 2001), before the glacier appeared to reach a new equilibrium. NPI-12 (Glaciar Benito) and NPI-13 (HPN-1) are both thinning rapidly and accelerated in speed between 2007 and 2011 (Willis and others, 2011). Neither glacier has shown significant shrinkage in this period.

For the SPI, the acceleration of shrinkage post-2001 is dominated by smaller fringing glaciers (Figs 4e, 5, 7b and $8 b)$. However, the majority of the large outlet glaciers draining the SPI calve into freshwater lakes or fjords, with highly variable behaviour in each catchment basin (Aniya, 1995; Fig. 8d). Dynamical changes in the calving glaciers of the SPI are discussed below. 
SPI-31 (Glaciar Upsala) calves into a lake on the eastern SPI and shrank at $0.2 \% \mathrm{a}^{-1}$ from 2001 to 2011. Previous studies observed thinning (33 m between 1990 and 1993; Naruse and Skvarca, 2000) and rapid area loss, and argued that this was caused by variations in bed topography, with bedrock rises in the lake controlling frontal fluctuations (Naruse and others, 1997; Naruse and Skvarca, 2000). SPI137 (Pio XI) is currently shrinking at a rate of $0.04 \% \mathrm{a}^{-1}$. From 1986 to 2001, Pio XI advanced at a rate of $0.01 \% \mathrm{a}^{-1}$, with a documented advance of up to $10 \mathrm{~km}$ from 1945 to 1986 (Rivera and Casassa, 1999), with thickening by an average of $44.1 \mathrm{~m}$ from 1975 to 1995.

SPI-16 (Glaciar Chico) is shrinking slower than many of the other large tidewater glaciers of the SPI (at $0.18 \% \mathrm{a}^{-1}$ ), which has been attributed to limited calving activity (Rivera and others, 2005). However, this glacier is thinning at rates comparable to other glaciers of the SPI, and the rate of area loss has accelerated in each successive period. SPI-14 (Glaciar O'Higgins) shrank most rapidly from 1870 to 1986 $\left(0.09 \% \mathrm{a}^{-1}\right)$, followed by slower shrinkage from 1986 to $2001\left(0.02 \% \mathrm{a}^{-1}\right)$ and from 2001 to $2011\left(0.01 \% \mathrm{a}^{-1}\right)$. This is largely due to a rapid retreat of $4.7 \mathrm{~km}$ from 1973 to 1976 (Lopez and others, 2010).

SPI-48 (Glaciar Perito Moreno), on the eastern side of the ice divide, calves into Lago Argentino (cf. Fig. 8b), with only limited area loss (0.1\%) after 2001. This glacier is well known for periodic advances and retreats, related to the geometry of its calving front. The glacier periodically advances to Península Magallanes, whereupon it dams the lake. Rising lake levels lead to increased pressure and eventual ice-dam and lake-drainage events through the ice front (Stuefer and others, 2007).

Therefore, across the NPI and SPI, atmospheric temperature changes have led to thinning, resulting in calving glaciers reaching flotation point and becoming unstable (cf. Rivera and Casassa, 2004). Stretching may cause short-lived advances, but encourages thinning and enhanced calving, resulting eventually in retreat. Accelerated retreat may occur after shrinkage from a pinning point (Holmlund and Fuenzalida, 1995; Warren and Aniya, 1999). Alternatively, a marine shoal may reduce water depths and encourage advance. The formation of a proglacial lake may accelerate glacier shrinkage, but if the glacier retreats beyond the lake margin, shrinkage may slow down. Therefore glacier shrinkage in calving glaciers is regulated by individual dynamics (calving status, ELA, channel geometry (Aniya and others, 1997)), with retreating, advancing and stable termini observed.

\subsection{Temporal and regional variations}

From Figures 4 and 5, it is clear that latitude, size and terminal environment exert the greatest controls on glacier shrinkage, with the more northerly, smaller, land-terminating glaciers shrinking fastest. Calving glaciers are changing in area (relative rates of area loss) more slowly than small landterminating glaciers, with internal calving dynamics controlling tidewater termini (Fig. 4a). The spikes in SPMG and Lago del Desierto are caused by a small number of very rapidly shrinking glaciers, such as EC-1, SPMG-15 and SPMG-5. Worldwide, small glaciers and ice caps have reacted particularly dynamically to increased global temperatures (Oerlemans and Fortuin, 1992; Hock and others, 2009), and it has been proposed that the volume loss from mountain glaciers and ice caps like these is the main contributor to recent global sea-level rise (Church and others, 2001; Braithwaite and Raper, 2002; Meier and others, 2007; Hock and others, 2009). On a regional scale, both the large icefields and small ice caps and glaciers north of $52^{\circ} \mathrm{S}$ have suffered accelerated shrinkage from 2001 to 2011 (Fig. 4e), presumably driven by the observed increases in uppertropospheric air temperatures since 1976, particularly at Puerto Montt (Giese and others, 2002; Villalba and others, 2003; Bown and Rivera, 2007; Carrasco and others, 2008; Aravena and Luckman, 2009; Rivera and others, 2012). Glacierized summits in the Chilean Lake District lie within this altitudinal zone, so this warming is likely to be a significant control on the mass balance of ice caps and glaciers between $41^{\circ} \mathrm{S}$ and $46^{\circ} \mathrm{S}$ in the far north of the study region, resulting in rapid shrinkage (i.e. Parque Nacional Vicente Rosales, Hornopirén, Parque Nacional Corcovado and Parque Nacional Queulat).

There is a very slight east-west gradient in annual rates of area loss for the NPI and SPI (Table 3), in particular for the period 1870-1986, with the eastern glaciers shrinking fastest. This is illustrated further in Figure 6, where smaller glaciers on the east of the NPI and the nearby glaciers exhibit the highest rates of relative shrinkage. We do not find strong evidence for shrinkage gradients in the outlet glaciers after 1986; this contrasts with other studies, where it has been argued that changes in precipitation are driving the accelerated shrinkage east of the ice divide (Aravena and Luckman, 2009). However, it should be noted that absolute rates of area loss $\left(\mathrm{km}^{2} \mathrm{a}^{-1}\right)$ are higher on the west of the ice divide, due to the larger glacierized area here. Harrison and Winchester (2000) also found little evidence of clear eastwest gradients or patterns of behaviour for the NPI. It is possible that declining precipitation drove increased relative shrinkage rates east of the ice divide for the period 1870 1986, but after this period more uniform shrinkage would suggest that they are more likely shrinking in response to thinning (cf. Rignot and others, 2003). Barcaza and others (2009) attribute faster absolute shrinkage $\left(\mathrm{km}^{2} \mathrm{a}^{-1}\right)$ on western glaciers to high transient snowlines and increased ablation areas; however, this does not take into account glacier size, so results are not comparable.

Mountain glaciers and ice caps between $52^{\circ} \mathrm{S}$ and $54^{\circ} \mathrm{S}$, including GCN and Isla Riesco, had relatively similar rates of area loss from 1986 to 2011 (Figs 4e and 6). The observed shrinkage is in keeping with thinning observed on outlet glaciers (Möller and others, 2007). Mountain glaciers south of $54^{\circ} \mathrm{S}$ and the Cordillera Darwin, Isla Hoste, Tierra del Fuego and Monte Sarmiento ice caps have had respectively less change since the LIA, which agrees with the findings of other studies (e.g. Kuylenstierna and others, 1996). These glaciers shrank fastest from 1986 to 2001 (Fig. 4e), during a period of rapid warming south of $46^{\circ} \mathrm{S}$ (Villalba and others, 2003).

\section{CONCLUSIONS}

We mapped glacier area and length for 640 Patagonian glaciers in 1870, and 626 glaciers for 1986, 2001 and 2011 (the remainder having entirely disappeared). The region is characterized by four large icefields and numerous small glaciers. These data provide the longest-term estimates (141 years) for regional glacier shrinkage of which we are aware. During this time, modelling and instrumented records show increases in atmospheric temperatures and reductions in precipitation. Almost all the glaciers shrank from their LIA limit. However, it was difficult to map this limit for some glaciers, and the area lost is a minimum estimate. For the 
first time, we have compared glacier length and area changes following the end of the LIA to change in recent decades, and have been able to compare rates of shrinkage both between icefields, but also for small isolated glaciers and ice caps across the study region, from $41^{\circ} \mathrm{S}$ to $56^{\circ} \mathrm{S}$.

Since $1870,90.2 \%$ of glaciers have shown continued and accelerating shrinkage. Small glaciers $\left(<5 \mathrm{~km}^{2}\right)$, mountain glaciers and ice caps around icefields in particular are shrinking very rapidly. We have demonstrated that mean glacier shrinkage is now faster than it was at the end of the LIA, with the NPI and SPI shrinking approximately twice as fast from 2001 to 2011 as from 1870 to 1986 . However, it should be noted that during the 116 years between observations, glaciers may have shrunk at rates higher or lower than the mean, with periods of stagnation or advance not accounted for during this period in our study.

The detailed analysis undertaken allows regional trends to be observed. Size, latitude and terminal environment exert the largest controls on glacier shrinkage, with smaller $\left(<5 \mathrm{~km}^{2}\right)$, land-terminating, northerly glaciers generally shrinking faster. For mountain glaciers north of $52^{\circ} \mathrm{S}$ and the NPI and the SPI, the period of fastest shrinkage was 200111. Glaciers in the Chilean Lake District and ice caps on volcanic mountains north of $46^{\circ} \mathrm{S}$ (which also have high mean elevations), and small mountain glaciers east of the SPI had the highest area loss rates, with accelerating shrinkage after 2001. Annual rates of area loss for mountain glaciers and ice caps north of $52^{\circ} \mathrm{S}$ are higher than for outlet glaciers of the NPI and the SPI, possibly because they are smaller.

There is considerable inter-catchment variability, and glaciers (particularly lacustrine and marine-terminating glaciers) have a nonlinear response to external forcings, and with shrinkage being regulated by calving processes and bedrock topography. Only two glaciers advanced beyond their LIA limits (possibly because of mapping difficulties), but several glaciers advanced from 1986 to 2001 and 2001 to 2011 . There is evidence for only very slight asynchronous shrinkage either side of the ice divide for the NPI and SPI. Calving outlet glaciers of the NPI and SPI are thinning and shrinking, but more slowly than land-terminating glaciers, and are controlled more by dynamic calving processes.

For GCN, Isla Riesco ice caps and small $\left(<5 \mathrm{~km}^{2}\right)$ mountain glaciers between $52^{\circ} \mathrm{S}$ and $54^{\circ} \mathrm{S}$, rates of area loss accelerated after 1986 and then remained stable, with similar rates of area loss from 2001 to 2011, and with many glaciers having no observable change. Mountain glaciers around GCN shrank fastest from 2001 to 2011. For the Cordillera Darwin, Isla Hoste and Monte Sarmiento ice caps and glaciers south of $54^{\circ} \mathrm{S}$, the period of fastest area loss was 1986-2001, with rates of area loss since declining, and increasing numbers of glaciers remained stable after 2001. There are clear differences in response between different regions, tidewater and land-terminating glaciers.

\section{ACKNOWLEDGEMENTS}

We acknowledge Masamu Aniya for kindly providing the shapefiles of the 1975 extent of the NPI. Landsat images were provided free of charge to Neil Glasser from NASA. This work was funded by a UK Natural Environment Research Council (NERC) grant through the Antarctic Funding Initiative (grant AFI 9-01; NE/F012942/1). We gratefully acknowledge constructive and thoughtful reviews from Frank Paul and Masamu Aniya.

\section{REFERENCES}

Aniya M (1988) Glacier inventory for the Northern Patagonia Icefield, Chile, and variations 1944/45 to 1985/86. Arct. Alp. Res., 20(2), 179-187

Aniya M (1995) Holocene glacial chronology in Patagonia: Tyndall and Upsala glaciers. Arct. Alp. Res., 27(4), 311-322

Aniya M (1996) Holocene variations of Ameghino Glacier, southern Patagonia. Holocene, 6(2), 247-252 (doi: 10.1177/ 095968369600600211)

Aniya M (1999) Recent glacier variations of the Hielo Patagónicos, South America, and their contribution to sea-level change. Arct. Antarct. Alp. Res., 31(2), 165-173

Aniya M (2001) Glacier variations of Hielo Patagónico Norte, Chilean Patagonia, since 1944/45, with special reference to variations between 1995/96 and 1999/2000. Bull. Glaciol. Res., 18, 55-63

Aniya M (2007) Glacier variations of Hielo Patagónico Norte, Chile, for 1944/45-2004/05. Bull. Glaciol. Res., 24, 59-70

Aniya M, Naruse R, Shizukuishi M, Skvarca P and Casassa G (1992) Monitoring recent glacier variations in the Southern Patagonia Icefield, utilizing remote sensing data. Int. Arch. Photogramm. Remote Sens., 29(B7), 87-94

Aniya M, Sato H, Naruse R, Skvarca P and Casassa G (1996) The use of satellite and airborne imagery to inventory outlet glaciers of the Southern Patagonia Icefield, South America. Photogramm. Eng. Remote Sens., 62(12), 1361-1369

Aniya M, Sato H, Naruse R, Skvarca P and Casassa G (1997) Recent glacier variations in the Southern Patagonia Icefield, South America. Arct. Alp. Res., 29(1), 1-12

Araneda A and 6 others (2007) Historical records of San Rafael glacier advances (North Patagonian Icefield): another clue to 'Little Ice Age' timing in southern Chile? Holocene, 17(7), 987-998 (doi: 10.1177/0959683607082414)

Aravena J-C and Luckman BH (2009) Spatio-temporal rainfall patterns in Southern South America. Int. J. Climatol., 29(14), 2106-2120 (doi: 10.1002/joc.1761)

Arendt AA, Echelmeyer KA, Harrison WD, Lingle CS and Valentine VB (2002) Rapid wastage of Alaska glaciers and their contribution to rising sea level. Science, 297(5580), 382-386 (doi: 10.1126/science.1072497)

Barcaza G, Aniya M, Matsumoto T and Aoki T (2009) Satellitederived equilibrium lines in Northern Patagonia Icefield, Chile, and their implications to glacier variations. Arct. Antarct. Alp. Res., 41(2), 174-182 (doi: 10.1657/1938-4246-41.2.174)

Bolch T, Menounos B and Wheate R (2010) Landsat-based inventory of glaciers in western Canada, 1985-2005. Remote Sens. Environ., 114(1), 127-137 (doi: 10.1016/j.rse.2009.08.015)

Bown F and Rivera A (2007) Climate changes and recent glacier behaviour in the Chilean Lake District. Global Planet. Change, 59(1-4), 79-86 (doi: 10.106/j.gloplacha.2006.11.015)

Braithwaite RJ and Raper SCB (2002) Glaciers and their contribution to sea level change. Phys. Chem. Earth, Parts $A / B / C$, 27(32-34), 1445-1454 (doi: 10.1016/S1474-7065(02)00089-X)

Buttstädt M, Möller M, Iturraspe R and Schneider C (2009) Mass balance evolution of Martial Este Glacier, Tierra del Fuego (Argentina) for the period 1960-2099. Adv. Geosci., 22, 117-124 (doi: 10.5194/adgeo-22-117-2009)

Carrasco JF, Osorio R and Casassa G (2008) Secular trend of the equilibrium-line altitude on the western side of the southern Andes, derived from radiosonde and surface observations. J. Glaciol., 54(186), 538-550 (doi: 10.3189/ 002214308785837002)

Casassa G, Smith K, Rivera A, Araos J, Schnirch M and Schneider C (2002) Inventory of glaciers in isla Riesco, Patagonia, Chile, based on aerial photography and satellite imagery. Ann. Glaciol., 34, 373-378 (doi: 10.3189/172756402781817671)

Chen JL, Wilson CR, Tapley BD, Blankenship DD and Ivins ER (2007) Patagonia Icefield melting observed by Gravity Recovery 
and Climate Experiment (GRACE). Geophys. Res. Lett., 43(22), L22501 (doi: 10.1029/2007GL031871)

Church JA and 7 others (2001) Changes in sea level. In Houghton JT and 7 others eds. Climate change 2001: the scientific basis. Contribution of Working Group I to the Third Assessment Report of the Intergovernmental Panel on Climate Change. Cambridge University Press, Cambridge, 639-693

Cook AJ, Fox AJ, Vaughan DG and Ferrigno JG (2005) Retreating glacier fronts on the Antarctic Peninsula over the past halfcentury. Science, 308(5721), 541-544 (doi: 10.1126/science. 1104235)

Davies BJ, Carrivick JL, Glasser NF, Hambrey MJ and Smellie JL (2012) Variable glacier response to atmospheric warming, northern Antarctic Peninsula, 1988-2009. Cryosphere, 6, 1031-1048

Evans IS (2006) Local aspect asymmetry of mountain glaciation: a global survey of consistency of favoured directions for glacier numbers and altitudes. Geomorphology, 73(1-2), 166-184 (doi: 10.1016/j.geomorph.2005.07.009)

Farr TG and 17 others (2007) The Shuttle Radar Topography Mission. Rev. Geophys., 45(2), RG2004 (doi: 10.1029/2005RG000183)

Frey H and Paul F (2012) On the suitability of the SRTM DEM and ASTER GDEM for the compilation of topographic parameters in glacier inventories. Int. J. Appl. Earth Obs. Geoinform., 18, 480-490 (doi: 10.1016/j.jag.2011.09.020)

Garreaud RD, Vuille M, Compagnucci R and Marengo J (2009) Present-day South American climate. Palaeogeogr., Palaeoclimatol., Palaeoecol., 281(3-4), 180-195 (doi: 10.1016/j. palaeo.2007.10.032)

Giese BS, Urizar SC and Fuckar NS (2002) Southern Hemisphere origins of the 1976 climate shift. Geophys. Res. Lett., 29(2), 1014 (doi: 10.1029/2001GL013268)

Glasser NF and Scambos TA (2008) A structural glaciological analysis of the 2002 Larsen B ice-shelf collapse. J. Glaciol., 54(184), 3-16 (doi: 10.3189/002214308784409017)

Glasser NF, Hambrey MJ and Aniya M (2002) An advance of Soler Glacier, North Patagonian Icefield, at c. AD 1222-1342. Holocene, 12(1), 113-120 (doi: 10.1191/0959683602hl526rr)

Glasser NF, Harrison S, Winchester V and Aniya M (2004) Late Pleistocene and Holocene palaeoclimate and glacier fluctuations in Patagonia. Global Planet. Change, 43(1-2), 79-101 (doi: 10.1016/j.gloplacha.2004.03.002)

Glasser NF, Jansson KN, Harrison S and Rivera A (2005) Geomorphological evidence for variations of the North Patagonian Icefield during the Holocene. Geomorphology, 71(3-4), 263-277 (doi: 10.1016/j.geomorph.2005.02.003)

Glasser NF, Jansson KN, Harrison S and Kleman J (2008) The glacial geomorphology and Pleistocene history of South America between $38^{\circ} \mathrm{S}$ and $56^{\circ} \mathrm{S}$. Quat. Sci. Rev., 27(3-4), 365-390 (doi: 10.1016/j.quascirev.2007.11.011)

Glasser NF, Harrison S, Jansson KN, Anderson K and Cowley A (2011) Global sea-level contribution from the Patagonian Icefields since the Little Ice Age maximum. Nature Geosci., 4(5), 303-307 (doi: 10.1038/ngeo1122)

Granshaw FD and Fountain AG (2006) Glacier change (19581998) in the North Cascades National Park Complex, Washington, USA. J. Glaciol., 52(177), 251-256 (doi: 10.3189/ 172756506781828782)

Harrison S and Winchester V (2000) Nineteenth- and twentiethcentury glacier fluctuations and climatic implications in the Arco and Colonia Valleys, Hielo Patagónico Norte, Chile. Arct. Antarct. Alp. Res., 32(1), 55-63

Harrison S, Winchester V and Glasser N (2007) The timing and nature of recession of outlet glaciers of Hielo Patagónico Norte, Chile, from their Neoglacial IV (Little Ice Age) maximum positions. Global Planet. Change, 59(1-4), 67-78 (doi: 10.1016/ j.gloplacha.2006.11.020)

Harrison S, Glasser NF, Duller GAT and Jansson KN (2012) Early and mid-Holocene age for the Tempanos moraines, Laguna San
Rafael, Patagonian Chile. Quat. Sci. Rev., 31, 82-92 (doi: 10.1016/j.quascirev.2011.10.015)

Hijmans RJ, Cameron SE, Parra JL, Jones PG and Jarvis A (2005) Very high resolution interpolated climate surfaces for global land areas. Int. J. Climatol., 25(15), 1965-1978 (doi: 10. 1002/joc.1276)

Hock R, De Woul M and Radić V (2009) Mountain glaciers and ice caps around Antarctica make a large sea-level rise contribution. Geophys. Res. Lett., 36(7), L07501 (doi: 10.1029/ 2008GL037020)

Holmlund P and Fuenzalida H (1995) Anomalous glacier responses to 20th century climatic changes in Darwin Cordillera, southern Chile. J. Glaciol., 41(139), 465-473

Ivins ER, Watkins MM, Yuan D-N, Dietrich R, Casassa G and Rülke A (2011) On-land ice loss and glacial isostatic adjustment at the Drake Passage: 2003-2009. J. Geophys. Res., 116(B2), B02403 (doi: 10.1029/2010JB007607)

Jarvis A, Reuter HI, Nelson A and Guevara E (2008) Hole-filled seamless SRTM data, V4. International Center for Tropical Agriculture (CIAT), Cali, http://srtm.csi.cgiar.org [accessed 31 July 2012]

Jiskoot H, Curran CJ, Tessler DL and Shenton LR (2009) Changes in Clemenceau Icefield and Chaba Group glaciers, Canada, related to hypsometry, tributary detachment, length-slope and areaaspect relations. Ann. Glaciol., 50(53), 133-143 (doi: 10.3189/ 172756410790595796)

Koch J and Kilian R (2005) 'Little Ice Age' glacier fluctuations, Gran Campo Nevado, southernmost Chile. Holocene, 15(1), 20-28 (doi: 10.1191/0959683605hl780rp)

Koppes M, Conway H, Rasmussen LA and Chernos M (2011) Deriving mass balance and calving variations from reanalysis data and sparse observations, Glaciar San Rafael, northern Patagonia, 1950-2005. Cryosphere, 5(3), 791-808 (doi: 10.5194/tc-5-791-2011)

Kuylenstierna J, Rosqvist GC and Holmlund P (1996) LateHolocene glacier variations in the Cordillera Darwin, Tierra del Fuego, Chile. Holocene, 6(3), 353-358 (doi: 10.1177/ 095968369600600310)

Lopez P, Chevallier P, Favier V, Pouyaud B, Ordenes F and Oerlemans J (2010) A regional view of fluctuations in glacier length in southern South America. Global Planet. Change, 71(1-2), 85-108 (doi: 10.1016/j.gloplacha.2009.12.009)

Masiokas $\mathrm{MH}$, Villalba R, Luckman BH, Lascano ME, Delgado S and Stepanek P (2008) 20th-century glacier recession and regional hydroclimatic changes in northwestern Patagonia. Global Planet. Change, 60(1-2), 85-100 (doi: 10.1016/ j.gloplacha.2006.07.031)

Masiokas M, Rivera A, Espizua LE, Villalba R, Delgado S and Aravena JC (2009a) Glacier fluctuations in extratropical South America during the past 1000 years. Palaeogeogr., Palaeoclimatol., Palaeoecol., 281(3-4), 242-268 (doi: 10.1016/ j.palaeo.2009.08.006)

Masiokas MH, Luckman BH, Villalba R, Delgado S, Skvarca P and Ripalta A (2009b) Little Ice Age fluctuations of small glaciers in the Monte Fitz Roy and Lago del Desierto areas, south Patagonian Andes, Argentina. Palaeogeogr., Palaeoclimatol., Palaeoecol., 281(3-4), 351-362 (doi: 10.1016/j.palaeo.2007.10.031)

Meier MF, Dyurgerov MB and McCabe GJ (2003) The health of glaciers: recent changes in glacier regime. Climatic Change, 59(1-2), 123-135

Meier MF and 7 others (2007) Glaciers dominate eustatic sea-level rise in the 21st century. Science, 317(5841), 1064-1067

Michel R and Rignot E (1999) Flow of Glaciar Moreno, Argentina, from repeat-pass Shuttle Imaging Radar images: comparison of the phase correlation method with radar interferometry. J. Glaciol., 45(149), 93-100

Montecinos A and Aceituno P (2003) Seasonality of the ENSOrelated rainfall variability in Central Chile and associated circulation anomalies. J. Climate, 16(2), 281-296 (doi: 10.1175/1520-0442(2003)016<0281:SOTERR>2.0.CO;2) 
Möller M and Schneider C (2008) Climate sensitivity and massbalance evolution of Gran Campo Nevado ice cap, southwest Patagonia. Ann. Glaciol., 48, 32-42 (doi: 10.3189/ 172756408784700626)

Möller M, Schneider C and Kilian R (2007) Glacier change and climate forcing in recent decades at Gran Campo Nevado, southernmost Patagonia. Ann. Glaciol., 46, 136-144 (doi: 10.3189/172756407782871530)

Naruse R and Skvarca P (2000) Dynamic features of thinning and retreating Glaciar Upsala, a lacustrine calving glacier in southern Patagonia. Arct. Antarct. Alp. Res., 32(4), 485-491

Naruse R, Skvarca P and Takeuchi Y (1997) Thinning and retreat of Glaciar Upsala, and an estimate of annual ablation changes in southern Patagonia. Ann. Glaciol., 24, 38-42

Oerlemans J and Fortuin JPF (1992) Sensitivity of glaciers and small ice caps to greenhouse warming. Science, 258(5079), $115-117$

Paul F (2002) Changes in glacier area in Tyrol, Austria, between 1969 and 1992 derived from Landsat Thematic Mapper and Austrian glacier inventory data. Int. J. Remote Sens., 23(4), 787-799 (doi: 10.1080/01431160110070708)

Paul F and 9 others (2009) Recommendations for the compilaton of glacier inventory data from digital sources. Ann. Glaciol., 50(53), 119-126 (doi: 10.3189/172756410790595778)

Racoviteanu AE, Paul F, Raup B, Khalsa SJS and Armstrong R (2009) Challenges and recommendations in mapping of glacier parameters from space: results of the 2008 Global Land Ice Measurements from Space (GLIMS) workshop, Boulder, Colorado, USA. Ann. Glaciol., 50(53), 53-69 (doi: 10.3189/ 172756410790595804)

Ramírez E and 8 others (2001) Small glaciers disappearing in the tropical Andes: a case-study in Bolivia: Glaciar Chacaltaya (16 ${ }^{\circ}$ S). J. Glaciol., 47(157), 187-194 (doi: 10.3189/ $172756501781832214)$

Raper SCB and Braithwaite RJ (2009) Glacier volume response time and its links to climate and topography based on a conceptual model of glacier hypsometry. Cryosphere, 3(2), 183-194 (doi: 10.5194/tc-3-183-2009)

Rau F, Mauz F, Vogt S, Khalsa SJS and Raup B (2005) Illustrated GLIMS glacier classification manual. Glacier classification guidance for the GLIMS inventory. Institut für Physische Geographie, Freiburg; National Snow and Ice Data Center, Boulder, CO

Raup B and Khalsa SJS (2010) GLIMS analysis tutorial. National Snow and Ice Data Center, Boulder, CO, http://www.glims.org/ MapsAndDocs/assets/GLIMS_Analysis_Tutorial_a4.pdf

Raup B and 11 others (2007a) Remote sensing and GIS technology in the Global Land Ice Measurements from Space (GLIMS) Project. Comput. Geosci., 33(1), 104-125 (doi: 10.1016/ j.cageo.2006.05.015

Raup B, Racoviteanu A, Khalsa SJS, Helm C, Armstrong R and Arnaud Y (2007b) The GLIMS geospatial glacier database: a new tool for studying glacier change. Global Planet. Change, 56(1-2), 101-110 (doi: 10.1016/j.gloplacha.2006.07.018)

Reuter HI, Nelson A and Jarvis A (2007) An evaluation of voidfilling interpolation methods for SRTM data. Int. J. Geogr. Inf. Sci., 21(9), 983-1008 (doi: 10.1080/13658810601169899)

Rignot E, Rivera A and Casassa G (2003) Contribution of the Patagonian icefields of South America to sea level rise. Science, 302(5644), 434-437 (doi: 10.1126/science.1087393)

Rivera A and Casassa G (1999) Volume changes on Pio XI glacier, Patagonia: 1975-1995. Global Planet. Change, 22(1-4), 233-244 (doi: 10.1016/S0921-8181(99)00040-5)

Rivera A and Casassa G (2004) Ice elevation, areal and frontal changes of glaciers from National Park Torres del Paine, Southern Patagonia Icefield. Arct. Antarct. Alp. Res., 36(4), 379-389

Rivera A, Casassa G, Bamber JL and Kääb A (2005) Ice-elevation changes of Glaciar Chico, southern Patagonia, using ASTER
DEMs, aerial photographs and GPS data. J. Glaciol., 51(172), 105-112 (doi: 10.3189/172756505781829557)

Rivera A, Bown F, Casassa G, Acuña C and Clavero J (2005) Glacier shrinkage and negative mass balance in the Chilean Lake District (40 ${ }^{\circ}$ ). Hydrol. Sci. J., 50(6), 963-974

Rivera A, Benham T, Casassa G, Bamber J and Dowdeswell JA (2007) Ice elevation and areal changes of glaciers from the Northern Patagonia Icefield, Chile. Global Planet. Change, 59(1-4), 126-137 (doi: 10.1016/j.gloplacha.2006.11.037)

Rivera A, Koppes M, Bravo C and Aravena JC (2011) Little Ice Age advance and retreat of Glaciar Jorge Montt, Chilean Patagonia, recorded in maps, air photographs and dendrochronology. Clim. Past Discuss., 7(5), 3131-3164 (doi: 10.5194/ cpd-7-3131-2011)

Rivera A, Bown F, Carrión D and Zenteno P (2012) Glacier responses to recent volcanic activity in Southern Chile. Environ. Res. Lett., 7(1), 014036 (doi: 10.1088/1748-9326/7/1/ 014036)

Rott H, Stuefer M, Siegel A, Skvarca P and Eckstaller A (1998) Mass fluxes and dynamics of Moreno Glacier, Southern Patagonia Icefield. Geophys. Res. Lett., 25(9), 1407-1410 (doi: 10.1029/ 98GL00833)

Sagredo EA and Lowell TV (2012) Climatology of Andean glaciers: a framework to understand glacier response to climate change. Global Planet. Change, 86-87, 101-109 (doi: 10.1016/ j.gloplacha.2012.02.010)

Scherler D, Bookhagen B and Strecker MR (2011) Spatially variable response of Himalayan glaciers to climate change affected by debris cover. Nature Geosci., 4(3), 156-159 (doi: 10.1038/ ngeo1068)

Schneider C, Schnirch M, Acuña C, Casassa G and Kilian R (2007) Glacier inventory of the Gran Campo Nevado Ice Cap in the Southern Andes and glacier changes observed during recent decades. Global Planet. Change, 59(1-4), 87-100 (doi: 10.1016/j.gloplacha.2006.11.023)

Stokes CR, Popovin V, Aleynikov A, Gurney SD and Shahgedanova M (2007) Recent glacier retreat in the Caucasus Mountains, Russia, and associated increase in supraglacial debris cover and supra-/proglacial lake development. Ann. Glaciol., 46, 195-203 (doi: 10.3189/172756407782871468)

Stuefer M, Rott H and Skvarca P (2007) Glaciar Perito Moreno, Patagonia: climate sensitivities and glacier characteristics preceding the 2003/04 and 2005/06 damming events. J. Glaciol., 53(180), 3-16 (doi: 10.3189/172756507781833848)

Svoboda F and Paul F (2009) A new glacier inventory on southern Baffin Island, Canada, from ASTER data: I. Applied methods, challenges and solutions. Ann. Glaciol., 50(53), 11-21 (doi: 10.3189/172756410790595912)

Tucker CJ, Grant DE and Dykstra JD (2004) NASA's global orthorectified Landsat data set. Photogramm. Eng. Remote Sens., 70(3), 313-322

Vaughan DG, Marshall GJ, Connolley WM, King JC and Mulvaney $\mathrm{R}$ (2001) Climate change: devil in the detail. Science, 293(5536), 1777-1779 (doi: 10.1126/science.1065116)

Villalba R (1994) Tree-ring and glacial evidence for the medieval warm epoch and the Little Ice Age in southern South America. Climatic Change, 26(2-3), 183-197 (doi: 10.1007/BF01092413)

Villalba R and 9 others (2003) Large-scale temperature changes across the southern Andes: 20th-century variations in the context of the past 400 years. Climatic Change, 59(1-2), 177-232 (doi: 10.1023/A:1024452701153)

Warren C and Aniya M (1999) The calving glaciers of southern South America. Global Planet. Change, 22(1-4), 59-77

Warren CR, Glasser NF, Harrison S, Winchester V, Kerr AR and Rivera A (1995) Characteristics of tide-water calving at Glaciar San Rafael, Chile. J. Glaciol., 41(138), 273-289

Willis MJ, Melkonian AK, Pritchard ME and Ramage JM (2011) Ice loss rates at the Northern Patagonian Icefield derived using a decade of satellite remote sensing. Remote Sens. Environ., 117,184-198 (doi: 10.1016/j.rse.2011.09.017) 
Winchester V and Harrison S (1996) Recent oscillations of the San Quintin and San Rafael Glaciers, Patagonian Chile. Geogr. Ann. A, 78(1), 35-49

Winchester V and Harrison S (2000) Dendrochronology and lichenometry: colonization, growth rates and dating of geomorphological events on the east side of the North Patagonian Icefield, Chile. Geomorphology, 34(3-4), 181-194 (doi: 10.1016/S0169-555X(00)00006-4)

World Glacier Monitoring Service (WGMS) (2008) Global glacier changes: facts and figures, ed. Zemp M, Roer I, Kääb A, Hoelzle M, Paul F and Haeberli W. World Glacier Monitoring Service/ United Nations Environment Programme, Zürich

\section{APPENDIX A}

List of images used in the inventory. All Landsat images are natural look with geographic reference. Landsat resolution $30 \mathrm{~m}$; swath $185 \mathrm{~km}$. Glacier extent in AD 1870 was mapped from 16 Landsat 7 ETM+ SLC-on images from 2000-01. Glacier extents in 1975 from Aniya (1988) map for the NPI (provided as shapefiles by Masamu Aniya). Inventory in 1987 from 20 Landsat 4-5 images. Inventory in 2001 from 16 Landsat 7 ETM+ SLC-on images. Inventory in 2011 from Landsat 7 ETM+ SLC-OFF images.

\begin{tabular}{|c|c|c|c|}
\hline Sensor & Image ID & Date & Path/row \\
\hline Landsat 7 ETM+ SLC-OFF & LE72320892011050EDC00 & 19 Feb 2011 & $232 / 89$ \\
\hline Landsat 7 ETM+ SLC-OFF & LE72320902011050EDC00 & 19 Feb 2011 & $232 / 90$ \\
\hline Landsat 7 ETM+ SLC-OFF & LE72320912011210COA00 & 29 Jul 2011 & $232 / 91$ \\
\hline Landsat 7 ETM+ SLC-OFF & LE72320922011050EDC00 & 19 Feb 2011 & $232 / 92$ \\
\hline Landsat 7 ETM+ SLC-OFF & LT52310932011299EDC01 & 26 Oct 2011 & $231 / 93$ \\
\hline Landsat 7 ETM+ SLC-OFF & LE72320932011050EDC00 & 19 Feb 2011 & $232 / 93$ \\
\hline Landsat 7 ETM+ SLC-OFF & LE72320942011050EDC00 & 19 Feb 2011 & $232 / 94$ \\
\hline Landsat 7 ETM+ SLC-OFF & LE72310942011347EDC00 & 13 Dec 2011 & $231 / 94$ \\
\hline Landsat 7 ETM+ SLC-OFF & LE72310952011299EDC00 & 26 Oct 2011 & $231 / 95$ \\
\hline Landsat 7 ETM+ SLC-OFF & LE72310952011347COA00 & 13 Dec 2011 & $231 / 95$ \\
\hline Landsat 7 ETM+ SLC-OFF & LE72320952011050EDC00 & 19 Feb 2011 & $231 / 95$ \\
\hline Landsat 7 ETM+ SLC-OFF & LE72320952011274ASN00 & 1 Oct 2011 & $232 / 95$ \\
\hline Landsat 7 ETM+ SLC-OFF & LE72310962010088EDC00 & 29 Mar 2010 & $231 / 96$ \\
\hline Landsat 7 ETM+ SLC-OFF & LE72300972007249ASN00 & 6 Sep 2007 & $230 / 97$ \\
\hline Landsat 7 ETM+ SLC-OFF & LE72270982011095EDC00 & 5 Apr 2011 & $227 / 98$ \\
\hline Landsat 7 ETM+ SLC-OFF & LE72270982010092EDC00 & 2 Apr 2010 & $227 / 98$ \\
\hline Landsat 7 EMT+ SLC-on & p226r099_7f2001214_z19_ps742 & 14 Dec 2001 & $226 / 99$ \\
\hline Landsat 7 EMT+ SLC-on & p227r0987f20020207_z19_pz742 & 7 Feb 2002 & $227 / 98$ \\
\hline Landsat 7 EMT+ SLC-on & p228r098_7f20010331_z19_ps742 & 31 Mar 2001 & $228 / 98$ \\
\hline Landsat 7 EMT+ SLC-on & p230r096_7f20010507_z18_ps742 & 7 May 2001 & $230 / 96$ \\
\hline Landsat 7 EMT+ SLC-on & LE72300972001216EDC00 & 4 Aug 2001 & $230 / 97$ \\
\hline Landsat 7 EMT+ SLC-on & p231r093_7f20010115_z18_ps742 & 15 Jan 2001 & $231 / 93$ \\
\hline Landsat 7 EMT+ SLC-on & p231r094_7f20011027_z18_ps742 & 27 Oct 2001 & $231 / 94$ \\
\hline Landsat 7 EMT+ SLC-on & p231r095_7f20011014_z18_ps742 & 14 Oct 2001 & $231 / 95$ \\
\hline Landsat 7 EMT+ SLC-on & p232r089_7f20011208_z18_ps742 & 8 Dec 2001 & $232 / 89$ \\
\hline Landsat 7 EMT+ SLC-on & p232r090_7f20011208_z18_ps742 & 8 Dec 2001 & $232 / 90$ \\
\hline Landsat 7 EMT+ SLC-on & p232r091_7f20011208_z18_ps742 & 8 Dec 2001 & $232 / 91$ \\
\hline Landsat 7 EMT+ SLC-on & p232r092_7f20010311_z18_ps742 & 3 Nov 2001 & $232 / 92$ \\
\hline Landsat 7 EMT+ SLC-on & p232r093_7f20010311_z18_ps742 & 11 Mar 2001 & $232 / 93$ \\
\hline Landsat 7 EMT+ SLC-on & p233r089_7f20011129_z18_ps742 & 29 Nov 2001 & $233 / 89$ \\
\hline Landsat 4-5 TM & LT52320891986053AAA03 & 22 Feb 1989 & $232 / 89$ \\
\hline Landsat 4-5 TM & LT52320901986229AAA08 & 17 Aug 1986 & $232 / 90$ \\
\hline Landsat 4-5 TM & LT52320911986229AAA08 & 17 Aug 1986 & $232 / 91$ \\
\hline Landsat 4-5 TM & LT52310911986270AAA04 & 27 Sep 1986 & $231 / 91$ \\
\hline Landsat 4-5 TM & LT52310911986270AAA04 & 27 Sep 1986 & $231 / 91$ \\
\hline Landsat 4-5 TM & LT52320911986117XXX02 & 27 Apr 1986 & $232 / 91$ \\
\hline Landsat 4-5 TM & LT52320921987040XXX02 & 15 Sep 1987 & $232 / 92$ \\
\hline Landsat 4-5 TM & LT52310931986270AAA03 & 27 Sep 1986 & $231 / 93$ \\
\hline Landsat 4-5 TM & LT523209311987040XXX02 & 9 Feb 1987 & $232 / 93$ \\
\hline Landsat 4-5 TM & LT52310941986270AAA11 & 27 Sep 1986 & $231 / 94$ \\
\hline Landsat 4-5 TM & LT52320941986277XXX02 & 4 Oct 1986 & $232 / 94$ \\
\hline Landsat 4-5 TM & LT52310951985027AAA03 & 27 Jan 1985 & $231 / 95$ \\
\hline Landsat 4-5 TM & LT52310951986270AAA02 & 27 Sep 1986 & $231 / 95$ \\
\hline Landsat 4-5 TM & LT52310961986014XXX04 & 14 Jan 1986 & $231 / 96$ \\
\hline Landsat 4-5 TM & LT52310961986014XXX04 & 14 Jan 1986 & $231 / 96$ \\
\hline Landsat 4-5 TM & LT52300971986279XXX03 & 6 Oct 1986 & $230 / 97$ \\
\hline Landsat 4-5 TM & LT52280981986057XXX02 & 26 Feb 1986 & $228 / 98$ \\
\hline Landsat 4-5 TM & LT52270981986258XXX03 & 15 Jun 1986 & $227 / 98$ \\
\hline Landsat 4-5 TM & LT52270981985143AAA02 & 23 May 1985 & $227 / 98$ \\
\hline Landsat 4-5 TM & LT52280981986057XXX02 & 26 Feb 1986 & $228 / 98$ \\
\hline
\end{tabular}




\section{APPENDIX B}

List of NASA SRTM DEM V4.1 tiles downloaded for this study from http://srtm.csi.cgiar.org. These images have a swath of $225 \mathrm{~km}$ and a resolution of $90 \mathrm{~m}$. All images date from February 2000.

\section{Path/row}

srtm_21-22

srtm_21_23

srtm_22_21

srtm_22_22

srtm_22_23

srtm_22_24
Path/row

srtm $23 \quad 21$

srtm_23_22

srtm_23_23

srtm_23_24

srtm_24_23

MS received 6 February 2012 and accepted in revised form 27 July 2012 